\title{
Estimation of Income Elasticity and Tax Capacity with Concentration on the Components of Tax Revenues in Khuzestan Province
}

\author{
Omid Hajati ${ }^{1}$ \\ Hassan Farazman ${ }^{2}$ \\ Seyed Morteza Afagheh ${ }^{3}$ \\ Seyed Aziz Armen ${ }^{4}$ \\ hfrazmand@scu.ac.ir \\ m.afghah@scu.ac.ir
}

\begin{abstract}
The purpose of this article is to estimate the income elasticity and tax capacity of Khuzestan province for policy-making and regional planning based on tax pay ability. To this end, the direct and indirect tax revenues of the province were estimated using the Seemingly Unrelated Equations approach, for the period 2000-2014. The results show that the direct and indirect tax revenue elasticity of Khuzestan province is 1.09 and 2.77 respectively, and the elasticity of total tax revenue is 1.34 . In addition, as for the direct tax, the tax elasticity of wealth and real estate is greater than the tax elasticity of businesses and corporations. The findings also indicate that the tax capacity of the province's businesses has a positive and significant relationship with the value-added of the restaurant and hotel sector as well as per capita income. Furthermore, the relationship between corporate tax capacity and value-added services is positive and significant. Likewise, the relationship between the tax capacity of other direct taxes (wealth and real estate) with real value-added and economic growth is positive and significant, and the relationship between the tax capacity of indirect taxes with private consumption expenditures and value-added of the mining sector is positive and significant.
\end{abstract}

Keywords: Tax Capacity, Income Elasticity, Direct Tax Revenues, Indirect Tax Revenues, SUR Method.

JEL Classification: H21, H71, H26.

1. Ph.D. Student, Department of Economics, and Social Sciences, Shahid Chamran University of Ahvaz, Khuzestan, Iran

2. Associate Professor, Department of Economics, and Social Sciences, Shahid Chamran University of Ahvaz, Khuzestan, Iran (Author Corresponding).

3. Associate Professor, Department of Economics, and Social Sciences, Shahid Chamran University of Ahvaz, Khuzestan, Iran.

4. Professor, Department of Economics, and Social Sciences, Shahid Chamran University of Ahvaz, Khuzestan, Iran. 


\section{برآورد كثش درآمدى وآمد ظرفيت مالياتى به تفكيك اجزاى درآمدهاى مالياتى در استان خوز فرستان}

دانشجوى دكترى كروه اقتصاد، دانشكده اقتصاد و علوم اجتماعى،

دانشعاه شهيد جمران اهواز، خوزستان، ايران.

hfrazmand@scu.ac.ir

m.afghah@scu.ac.ir

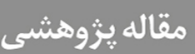

حسن فرازمند

دانشيار گروه اقتصاد، دانشكده اقتصاد و علوم اجتماعى، دانشگاه شهيد

جمران اهواز، خوزستان، ايران، (نويسنده هسئول)..

سيدمر تضى افقه

دانشيار گروه اقتصاد، دانشكده اقتصاد و علوم اجتماعى، دانشخاه شهيد

جمران اهواز، خوزستان، ايران.

سيدعزيز آرمن أروان

استاد كروه اقتصاد، دانشكده اقتصاد و علوم اجتماعى، دانشخاه شهيد جمران اهواز، خوزستان، ايران.

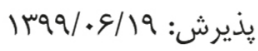

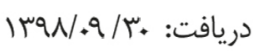

هُكيده: هدف يزوهش حاضر، تخمين كشش در آمدى و ظرفيت مالياتى استان خوزستان

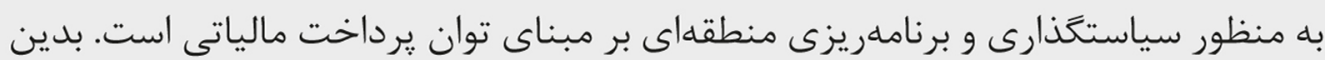

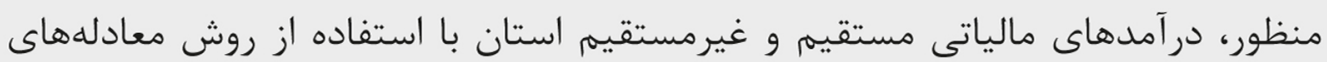

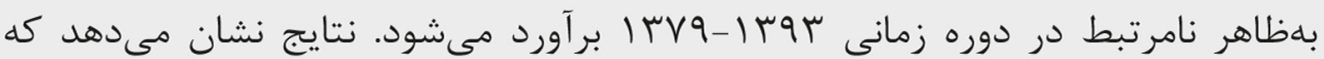

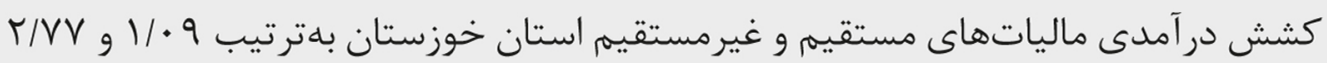

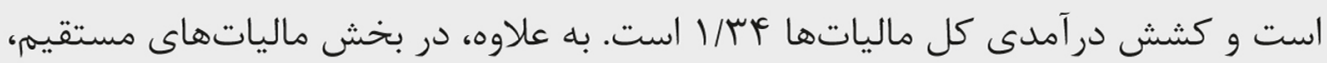

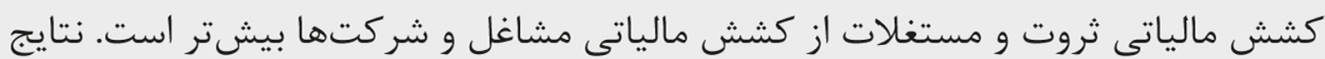

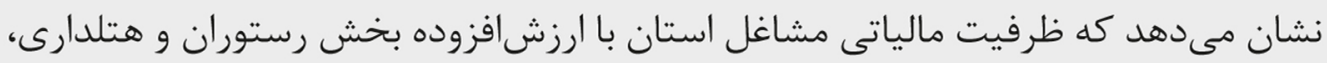

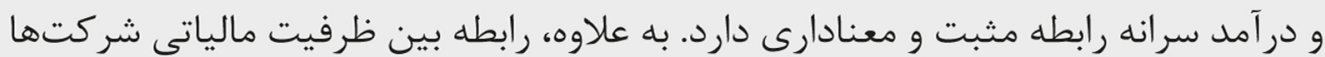

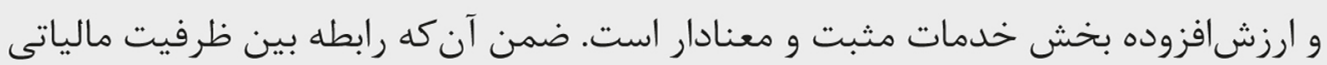

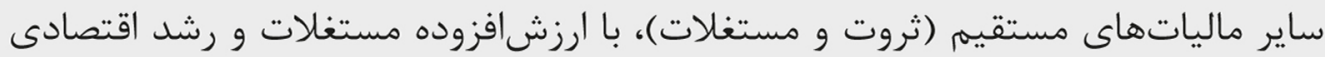

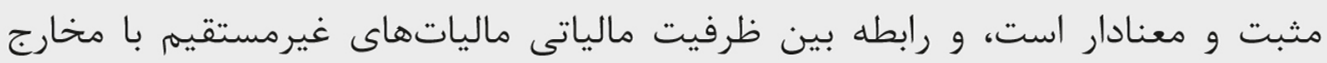
مصرفى بخش خصوصى و ارزشافزوهه بخش معدن مثبت و معنادار است.

كليدوازهها: ظرفيت مالياتى، كشش در آمدى، درآمدهاى مالياتى مستقيم، درآمدهاى مالياتى غيرمستقيهم، روش SUR. طبقهبندى H21, H71, H26 :JEL. 


\section{مقدمه}

امروزه تفويض اختيار مالياتهاى محلى و استانى در تحولهاى اخير مالياتى جايعاه خاصى دارند

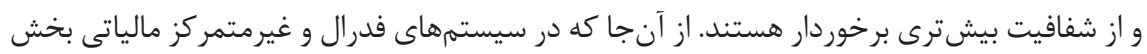
بزرگى از درآمد مالياتى صرف منطقه، استان، و محل مى شود، يرداخت كنند شدن و مصرف ماليات يرداختى خود را مشاهده مىكنند و اين موضوع موجب كاهش انكيزه فرار

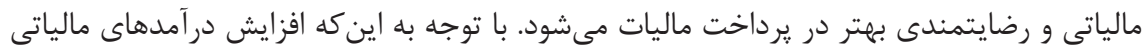

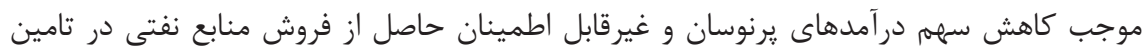
مالى بودجه مى گردد، مىتوان انتظار داشت كه ايجاد اين شرايط و بهبود نظام مالياتستانى موجب

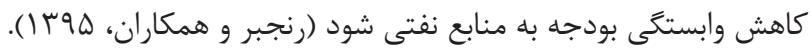

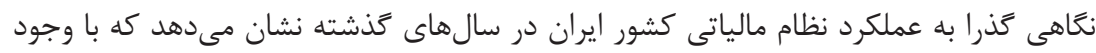

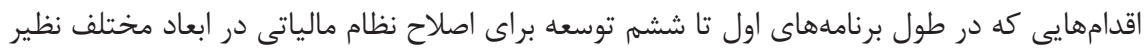
اصلاح قوانين و مقررات مالياتها، اصلاح نرخها، و معافيتهاى مالياتى انجام مىشود، ولى نظام

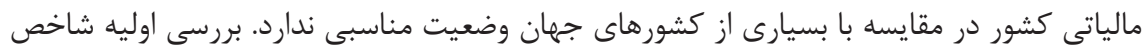

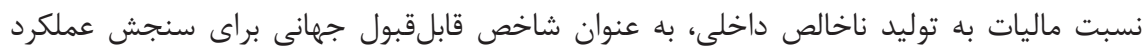

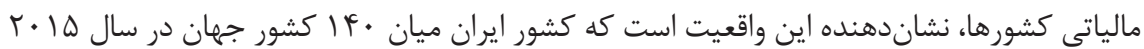
در جايعاه هץا قرار دارد (www.worldbank.org)'. به علاوه، نسبت ماليات به توليد ناخالص داخلى كشور در سال ها • r معادل V/D درصد است كه نصف رقم ميانگين جهانى است. به نظر اقتصاددانان

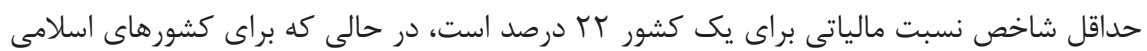

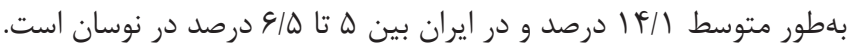

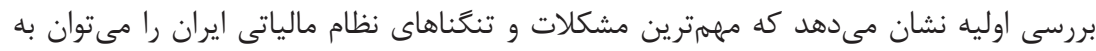

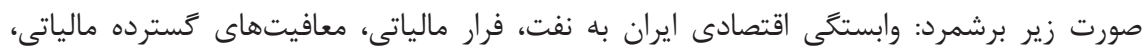
بى كشش بودن نظام مالياتى، و وقفه در جمعآورى ماليات. يكى از اقدامهاى اساسى كه امروزه براى اصلاح ساختار اقتصادى و افزايش عملكرد بخش عمومى مورد توجه اقتصاددانان است، نظريه تمركززدايى مالى است كه اهداف عمدهاى نظير كارايى، كاهش نابر ابرى ميان مناطق، تثبيت اقتصادى، و رقابت بينمنطقهاى را در بر مى گيرد. تمركززدايى مالى، فرايند انتقال قدرت تصميمگيرى نسبت به به نحوه مصرف مخارج و جمعآورى در آمدهاى مالياتى از دولت مركزى به دولتهاى مدرئ محلى است (ماسكريو 


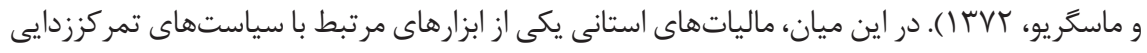

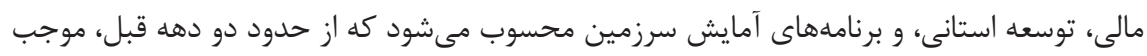

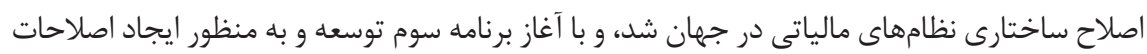

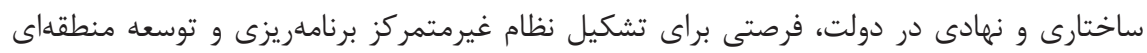

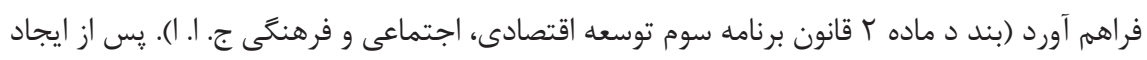

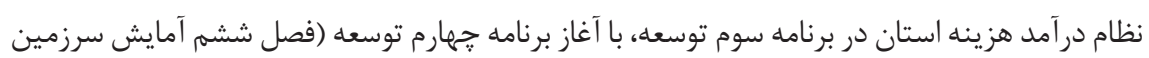

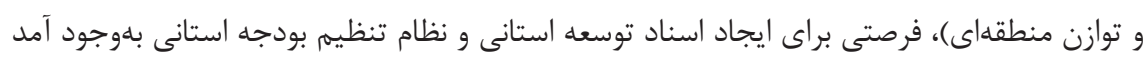

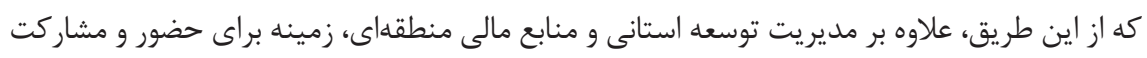

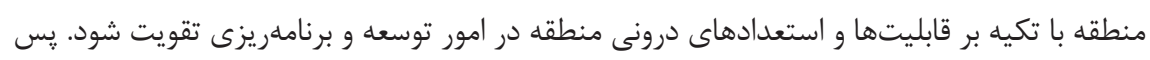

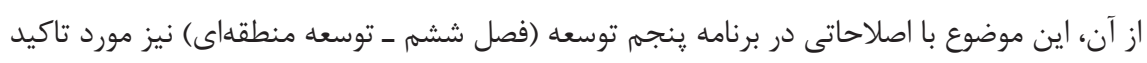

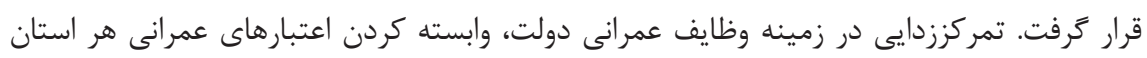

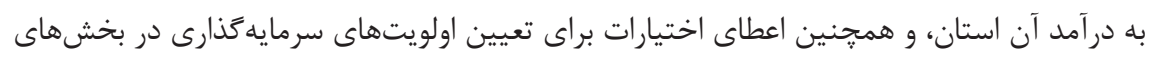

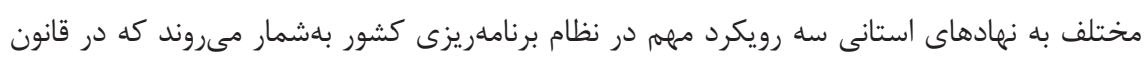

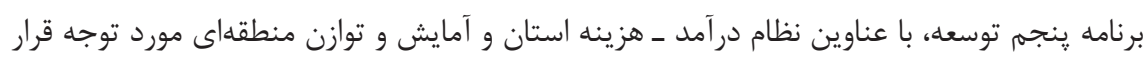

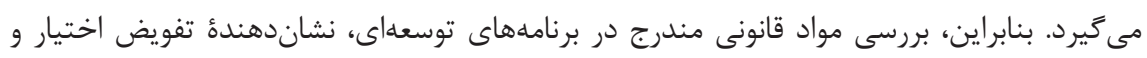

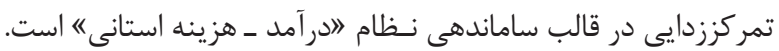

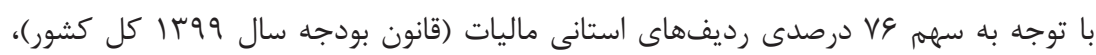

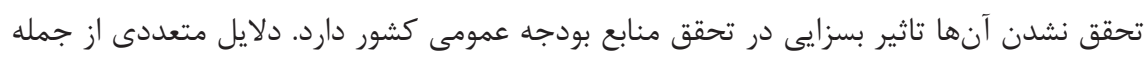

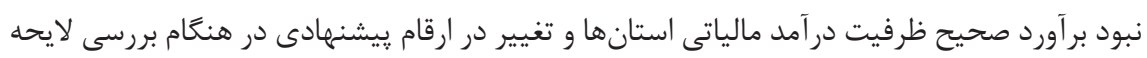

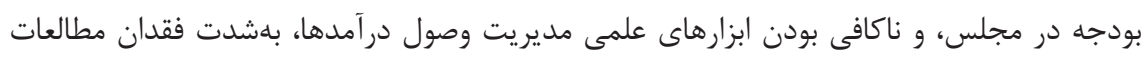

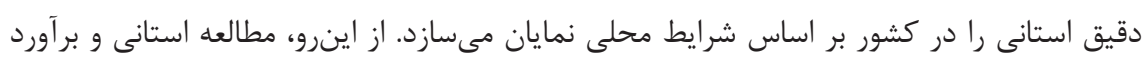

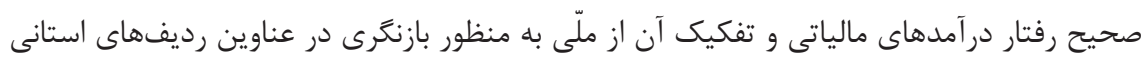

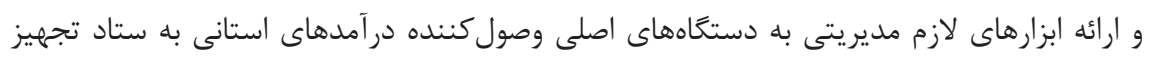

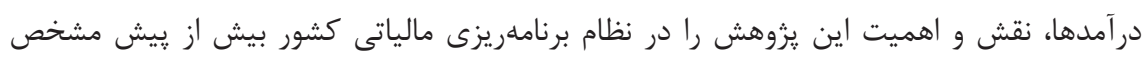

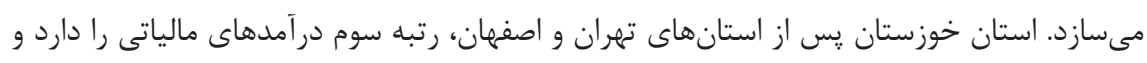

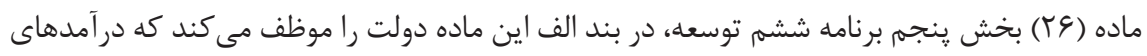

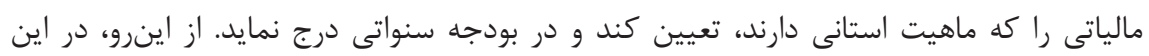


يروهش سعى مىشود با استفاده از تحليلهاى كمّى در قالب الكوهاى اقتصادسنجى به اين :برسش

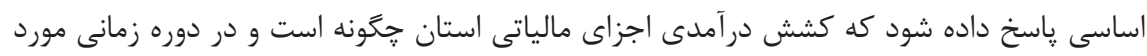
بررسى، اجزاى در آمدهاى مالياتى نسبت به عوامل موثر جه واكنشى از خود نشان مى دهند. بدين منظور، يزوهش حاضر در شش بخش تنظيمى مىشود. يس از مقدمه، در بخش دوم مبانى نظرى،

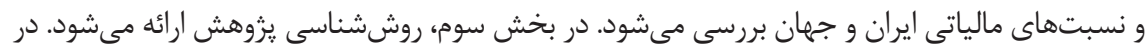

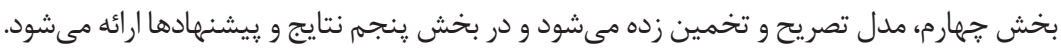

\section{مبانى نظرى بزوهش}

نياز هر دولتى به منابع مالى براى ايفاى وظايف و مسئوليتهايى مانند تامين و حراست از مرزها،

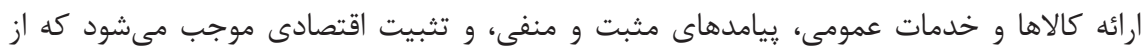

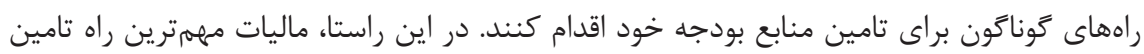
اعتبار از آغاز شكل گيرى جوامع و دولتهاست تامين منايع بودجه ماليات جدا از نقش اصلى خود، يعنى تامين اعتبار مالى دولت، نقشهاى كليدى ديخرى مانند تثبيت اقتصادى، كاهش نوسانهاى اقتصادى، هدايت فعاليتها، و توزيع مجدد درآمد را نيز بر عهده دارد. از اينرو، برآورد ظرفيت مالياتى براى شناخت ماتى

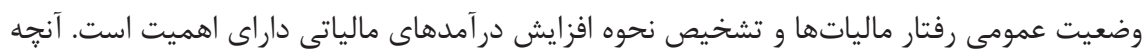

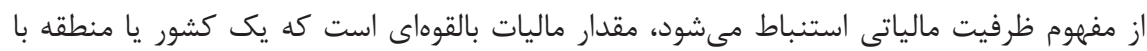
توجه به يايههاى مالياتى و حجم يولى فعاليتهاى اقتصادى امكان دريافت آن را در هر دوره زمانى

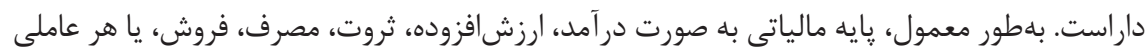

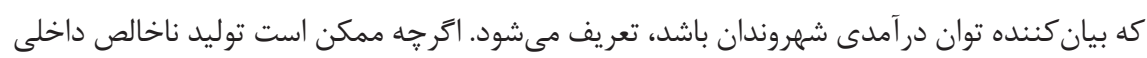

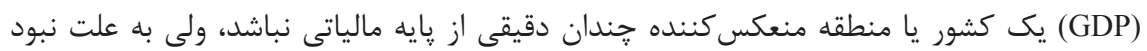
معيار جايكز ين مناسبتر، از GDP به عنوان קايه اصلى مالياتى در يك كشور يا منطقه استفاده مىشود

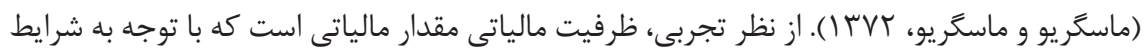

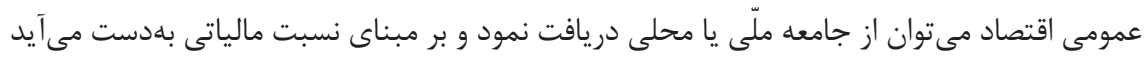
(Musgrave, 1987). نسبت مالياتى به مشخصههايى بستكى دارد كه جنبههاى مختلف سيستم

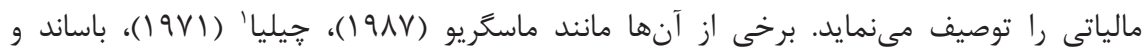




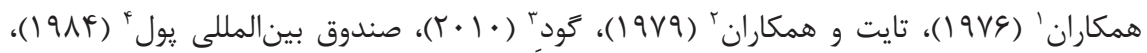

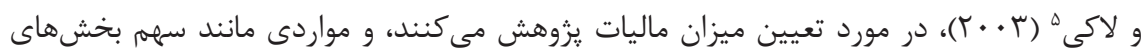

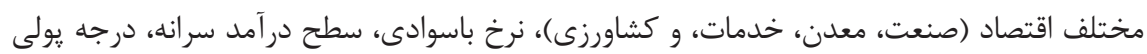
شدن اقتصاد، و نسبت صادرات و واردات به توليد ناخالص داخلى را از جمله مهلمترين عوامل كمّى موثر بر ظرفيت مالياتى تعريف مىكنند. در حالى كه عوامل موثر كيفى بر نسبت مالياتى در يك

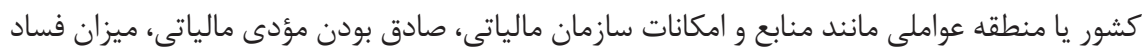

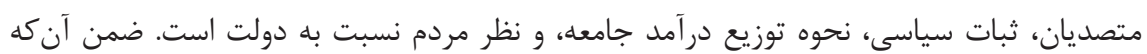
سياستها و قوانين مالياتى نقش موثرى در نسبت مالياتى ايفا مىنمايند.

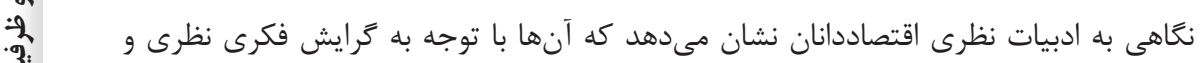

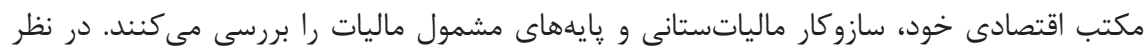

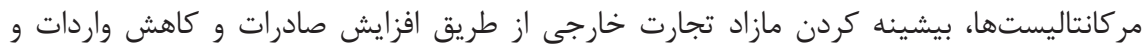
انباشت ذخاير طلا اهداف اصلى سياستهاى اقتصادى هستند، و در اين راستا فعاليتهاى توليدى داخل و نيز تجارت داخلى تشويق مىشود. به همين دليل، با هر نوع ماليات داخلى، عوارض جادهاى، و و ودائ

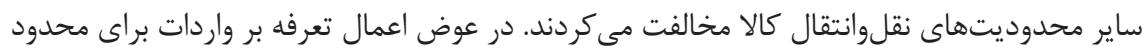

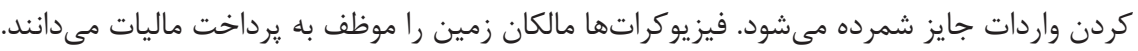

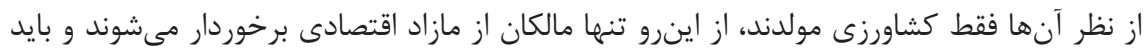

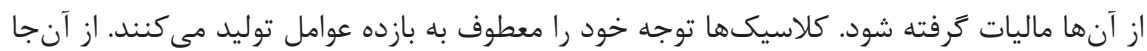
كه در دوره كلاسيكها صنعت توسعه مىيابد، دو عامل توليد دوره فيزيوكراتها يعنى زمين و سرمايه با وجود يديده كار به سه عامل تبديل مىشود. طرح اين عامل جديد توليد، بررسى عوامل مشمول

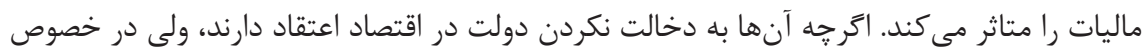
تامين مخارج عمومى از محل درآمدهاى مالياتى در حدى كه تعادل بودجه حفظ شود، باور دارند. ظهور كينز و نظريه او، توجيه حضور دولت و دخالت او را در راستاى حفظ ثبات اقتصادى تقويت مى كند، به اين ترتيب، سياستهاى اقتصادى و در راستاى آن مالياتها از اهميت ويزهاى برخوردار

1. Basand et al.

2. Tait et al.

3. Goode

4. www.imf.org

1.1 5. Luky

6. Keynes 
مىشود. به عبارت ديخر، از نظر كنيز ماليات نهفقط براى تامين هزينهای توليد كالاهاى عمومى، بلكه براى اجراى سياستهاى اقتصادى دولت نيز كارامد است. در اقتصاد اسلامى پايههاى مالياتى ثابت (مانند خمس و زكات)، و مالياتهاى حكومتى (متغير) تامين كننده مخارج دولت، توسعه اقتصادى، و توزيع در آمد است. بنابراين در هر مكتب اقتصادى، ضرورت

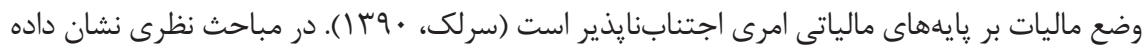
مىشود كه مالياتهاى مبتنى بر درآمد و ثروت (ماليات مستقيم)، قابليت انتقال كمترى به ديكران دارند و مالياتهايى مانند ماليات بر مصرف (ماليات غيرمستقيم)، بيشتر به ديكران انتقال يذير هستند.

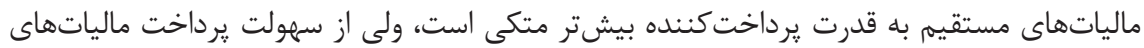

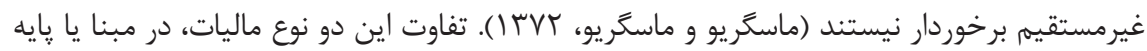

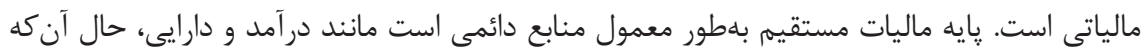

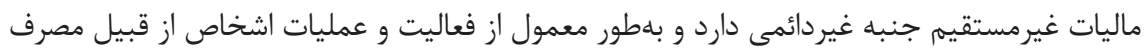

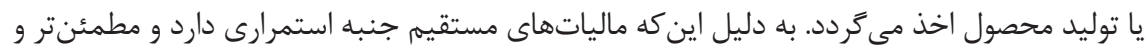

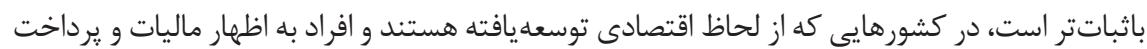
آن عادت دارند و آن را وظيفه اجتماعى خود مىدانند، وصول آن آسانتر و مخارج وصول آن نيز كمتر است يس، مالياتهاى غيرمستقيهم به دليل سادگى وصول، سادهترين راه براى تامين نيازهاى درآمدى

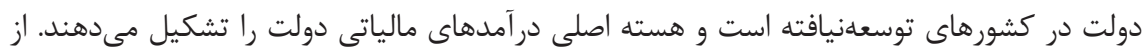
لحاظ عدالت مالياتى، ماليات مستقيهم بر ماليات غيرمستقيم برترى دارد، زيرا ماليات غيرمستقيم باططور

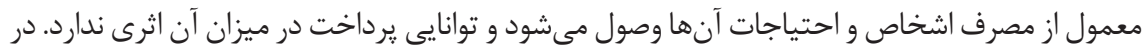

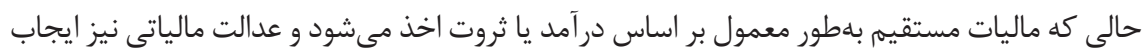

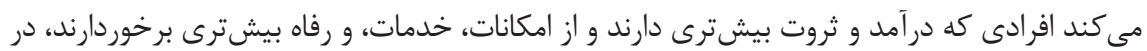
تقبل هزينههاى دولت سهمم بيشترى داشته باشند. از نظر "اديو"'و "فريدلندر "'، مالياتهايى را مستقيم

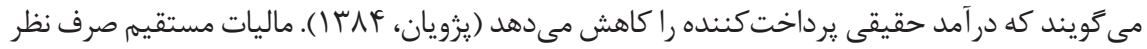
از سياست مالى براى اجراى سياست اقتصادى و اجتماعى دولت مناسبتر از ماليات غيرمستقيم است.

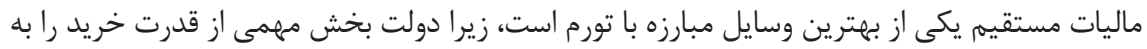
وسيله ماليات جمع آورى مى كند و از تقاضاى افراد براى خريد كالا مى كاهد. همجنين، مى تواند از طريق

1. Due

2. Friedlander 
معافيتهاى خاص به فعاليتهاى مولد و برقرارى نرخهاى تصاعدى مالياتى در رابطه با فعاليتهايى كه براى رشد اقتصادى كشور زيانبار تشخيص داده مىشوند، سياستهاى خاص اقتصادى اعمال نمايد. البته اجراى سياستهاى اقتصادى و اجتماعى از طريق مالياتهاى غيرمستقيم نيز تا حدودى جشمخير است،

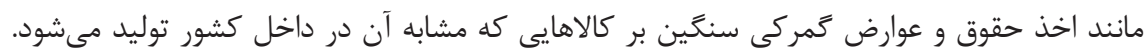
ماليات مستقيم از لحاظ سياست اقتصادى و اجتماعى مناسبتر از ماليات غيرمستقيم است. ولى ماليات

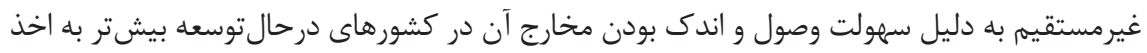

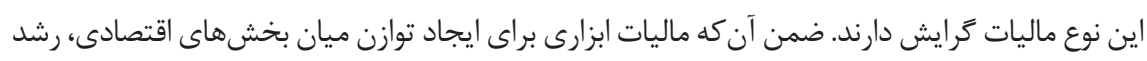

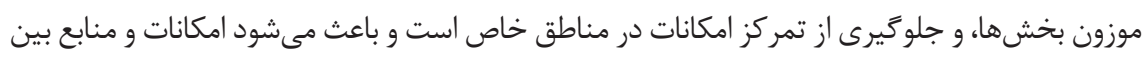

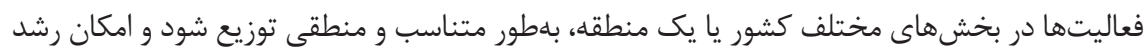
را براى افراد منطقه بلهطور كارامد فراهم كند.

در مورد ظرفيت مالياتى و كششهاى مالياتى يزوهشهاى زيادى وجود دارد. به عقيده جيلييا

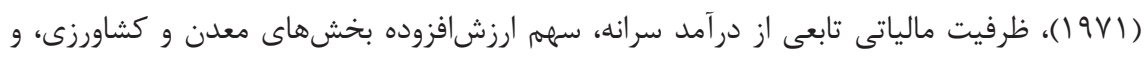

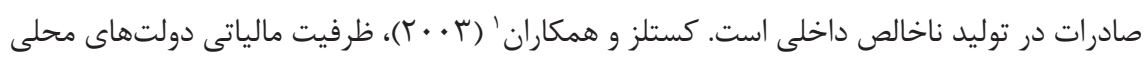

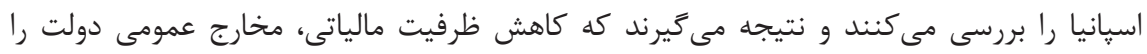

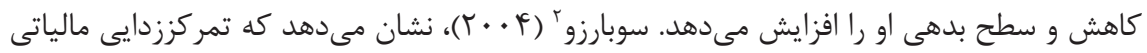

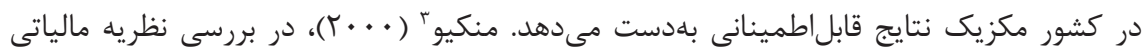

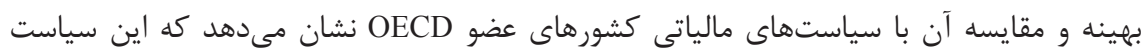

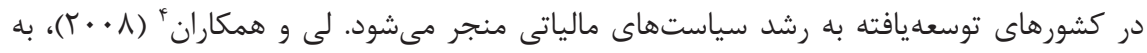

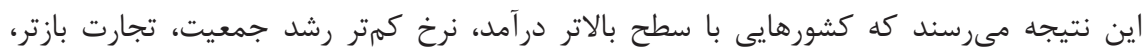

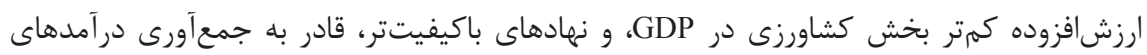

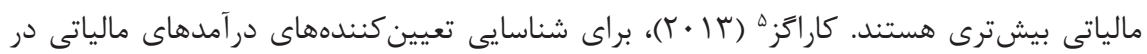
تر كيه نشان مى دهد كه بخش كشاورزى بر نسبت مالياتى اثر منفى دارد، در حالى كه بخش صنى صنعت،

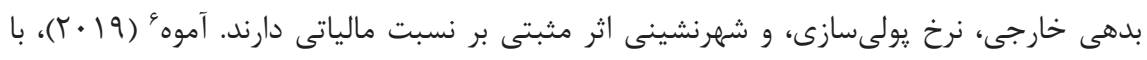

1. Castells et al.

2. Sobarzo

3. Mankiw

4. Le et al. 
بررسى ظرفيت و كوشش مالياتى كشور غنا نشان مىدهد كه در يك كشور درحالتوسعه، كارايى

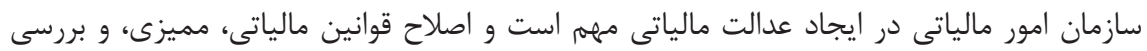
سريع وضعيت مالياتى نقش مهمى در توسعه اقتصادى كشور دارند.

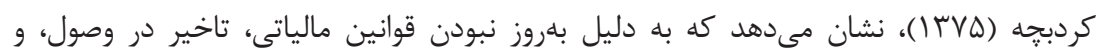

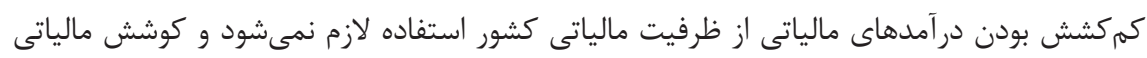

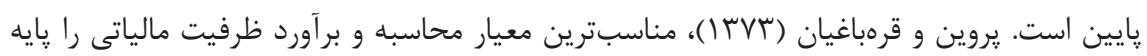

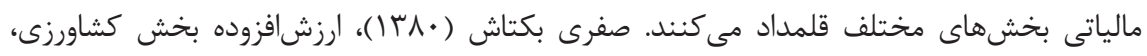
صنعت، و معدن و ارزشافزوده بخش خدمات را از عوامل موثر بر ظرفيت مالياتى استانى تعريف ميى كند.

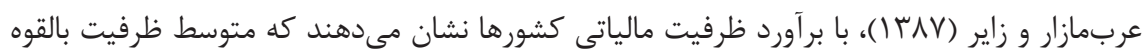

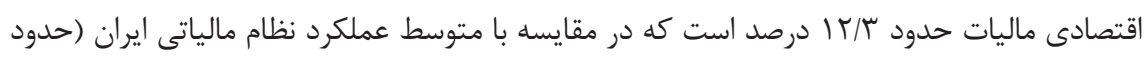

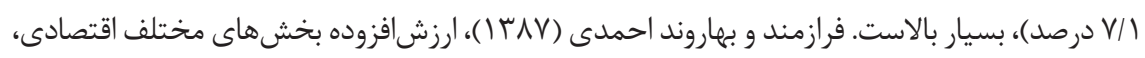

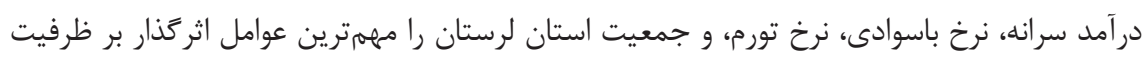

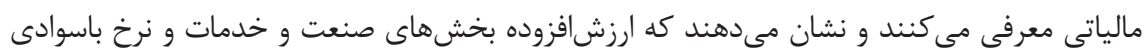
تاثير مثبت دارند، ولى ارزشافزوده بخشهاى معى معدن و كشاورزى، در آمد سرانه، نرخ تورم، و جمعيت رابطه

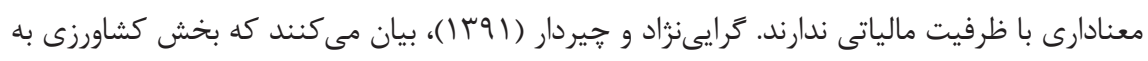

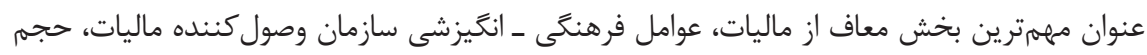

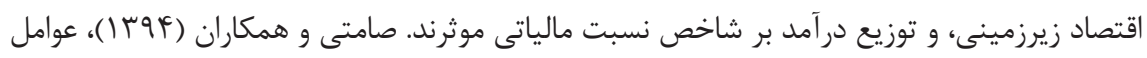

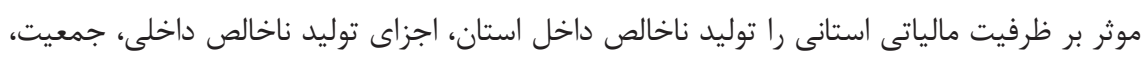

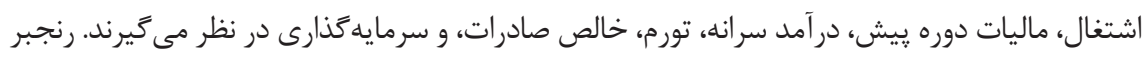

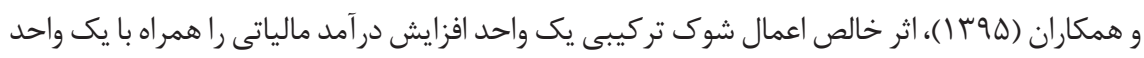

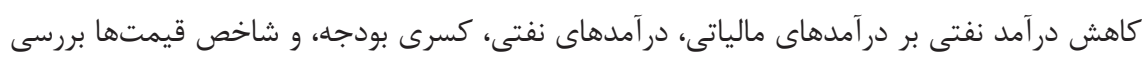

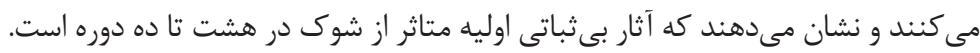




\section{بر رسى وضعيت و جايگًاه مالياتى استان خوزستان}

الف. بررسى جايعاه مالياتستانى استانى در جار گوب قوانين برنامههاى هنجساله و بودجه

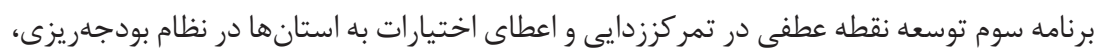

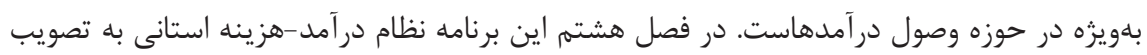

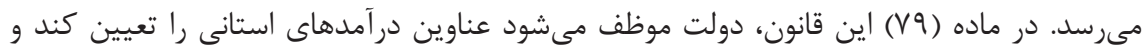

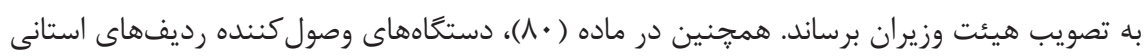

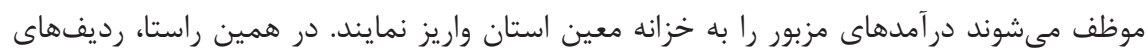

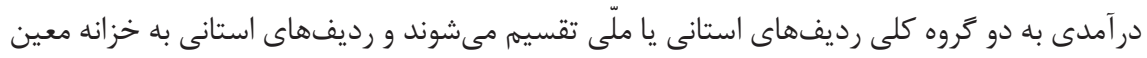

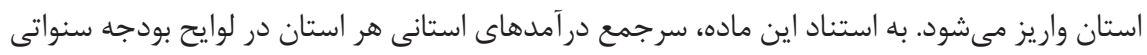

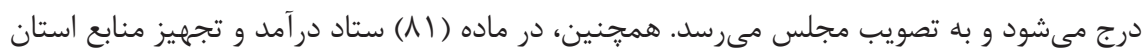

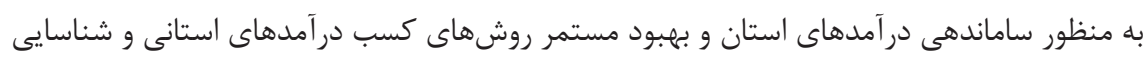
منابع جديد درآمدى تشكيل مىشود. ماده (V9)، از مواد مترقى اين برنامه در راستاى ايجاد انكًيزه

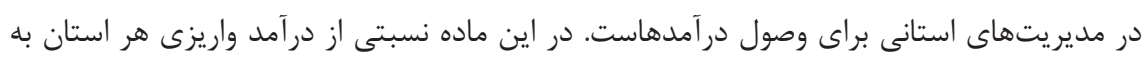

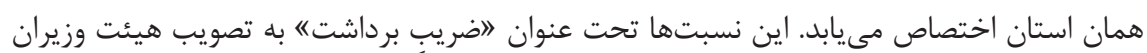

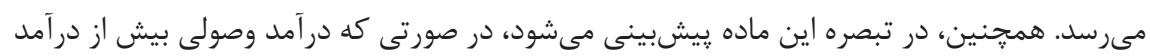

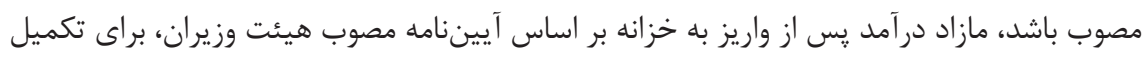

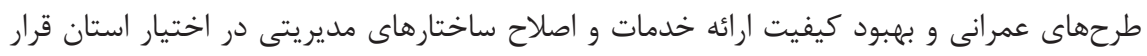

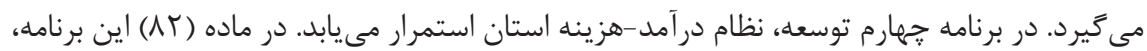

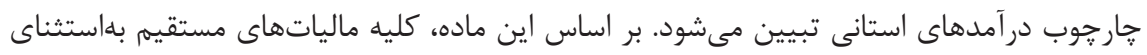

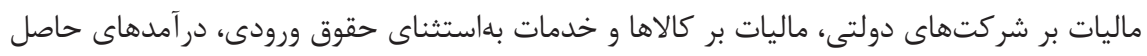

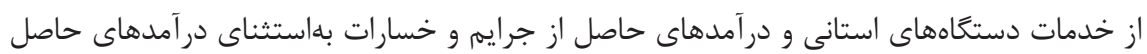
از جرايمم مبارزه با قاحاق و مواد مخدر درآمدهاى استانى تشخيص داده مى شود كه بايد به خزانه

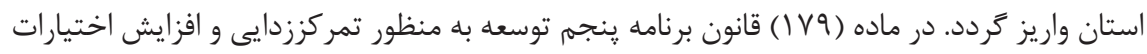

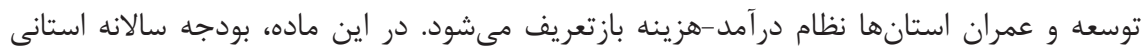

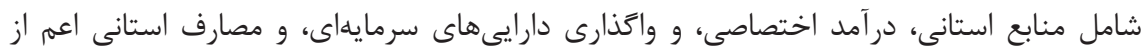

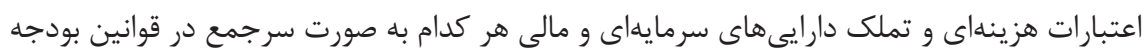


سنواتى درج مى گردد. با توجه به اينكه درآمدهاى استانى بر اساس عملكرد استانها در سالهاى

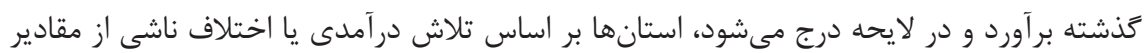

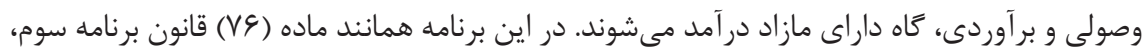
سازوكارى براى ايجاد انخيزه در وصول در آمدها در بند "اى" ماده (YYF) تعريف مىشود. بر اساس

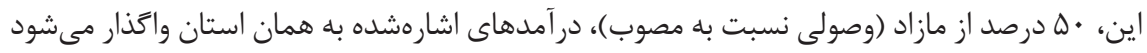

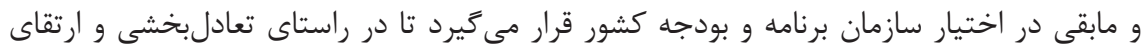

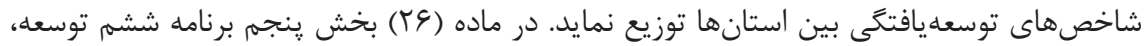

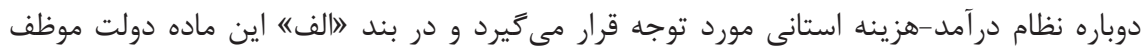

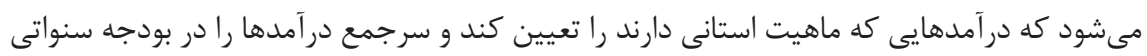
درج نمايد. مازاد بر درآمد وصولى نسبت به سقف هر استان بر اساس دستورالعمل ابلاغى سازمان براى تامين اعتبارات هزينهاى و تملك دارايىهاى سرمايهاى قانون بودجه بين استانهاى ذىىربط

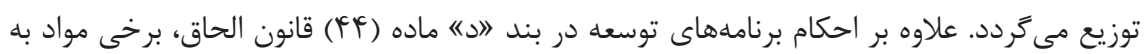

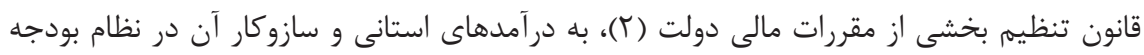
اشاره مىشود. بر اساس اين، سازمان برنامه و بودجه كشور سهمم هر استان از درآمدهاى استانى را به

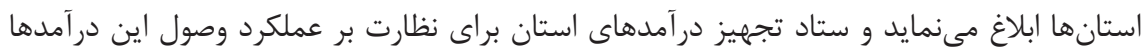
تشكيل مى گر دد. عناوين در آمدها و تفكيك در آمدهاى استانى از ملّى در جدول ( (1)، ماده واحد لايحه بودجه توسط

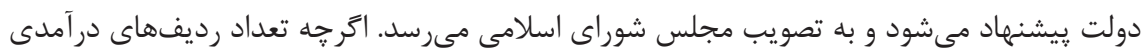

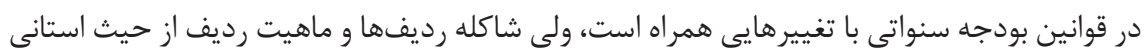

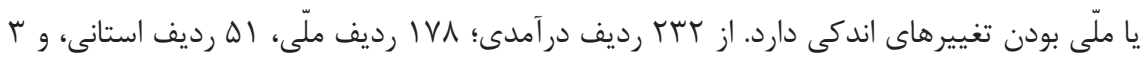

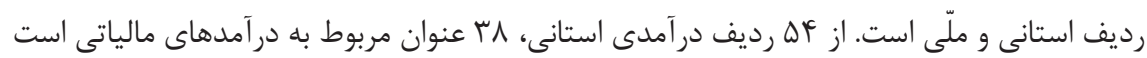

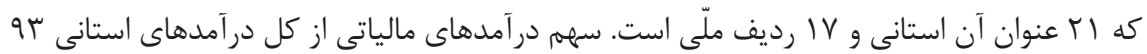
درصد است. در جدول (1)، تصوير وضعيت رديفهاى استانى در ساختار مالياتى كشور بر اساس قانون

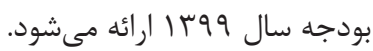




\section{جدول 1: وضعيت رديفهاى استانى در ساختار مالياتى كشور بر اساس قانون بودجه سال 99\%1}

\begin{tabular}{|c|c|c|c|c|c|}
\hline \multirow{2}{*}{ 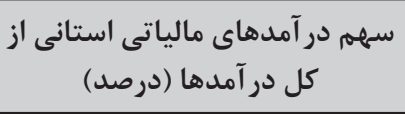 } & \multicolumn{3}{|c|}{ تعداد رديفها } & \multirow{2}{*}{ عنوان } & \multirow{2}{*}{ ماليات } \\
\hline & استانى & ملّى & كل & & \\
\hline $9 V$ & 1 & $\Delta$ & 9 & اشخاص حقوقى & \multirow{3}{*}{ در آمد } \\
\hline 99 & $\Delta$ & 1 & 4 & اشخاص حقيقى & \\
\hline $1 \cdots$ & $\wedge$ & · & $\wedge$ & ثروت & \\
\hline · & . & v & V & واردات & \multirow[b]{2}{*}{ مصرف } \\
\hline 9. & v & q & 11 & كالاها و خدمات & \\
\hline Ve & rI & IV & rᄉ & & كل \\
\hline
\end{tabular}

با توجه به سهم V درصدى رديفهاى استانى مالياتى، نبود تحقق آنها تاثير بسزايى در تحقق منابع بودجه عمومى كشور دارد. دلايل متعددى از جمله بىثباتى شرايط اقتصادى كشور و وقوع ركود اقتصادى، نبود بر آورد صحيح ظرفيت درآمدى استانها، تغيير در ارقام يیشنههادى در هنخام بررسى لايحه بودجه در مجلس، نبود انخيزه لازم براى وصول در آمدهاى استانى توسط مديريتهاى استانى، و در نتيجه

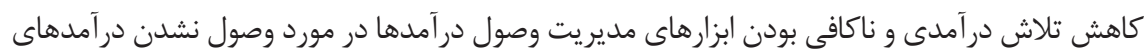

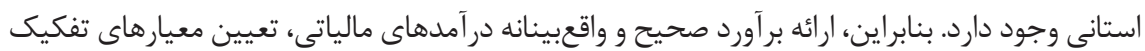

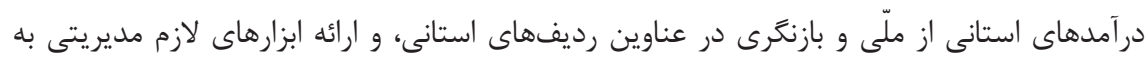

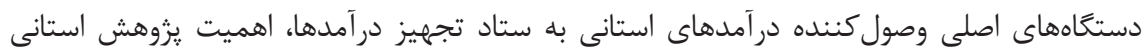

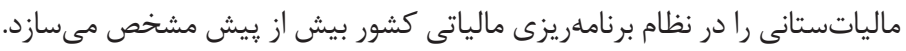

\section{نغاهى به جايعًاه مالياتى استان خوزستان در مقايسه با ايران و جههان}

اهميت و كاربردى كه حسابهاى ملّى در يزوهشها و بررسىهاى اقتصادى و اجتماعى كل كشور دارند، در حسابهاى منطقهاى يا استانى در سطح استان نيز به عهده دارند. استخراج ارزشافزوده

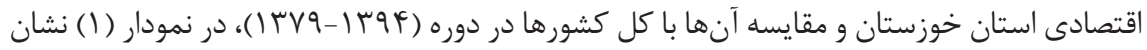

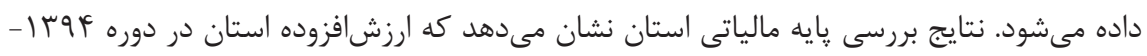

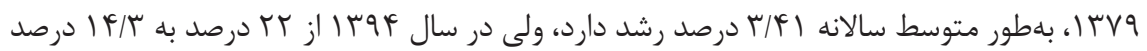
كل كشور كاهش مى يابد. رابطه بين پايه مالياتى ارزشافزوده بخشهاى صنعت و خدمات با در آمدهاى 
مالياتى در نمودارهاى (r) و (Y)، بهروشنى ارتباط آنها را نشان مى دهد. در نمودار (I)، جايعاه اين

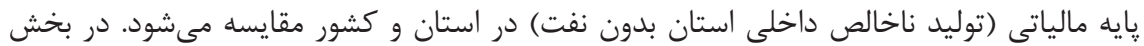
ادبيات يروهش اشاره مىشود كه نسبت ماليات به توليد ناخالص داخلى يكى از شاخصهاى مهرم

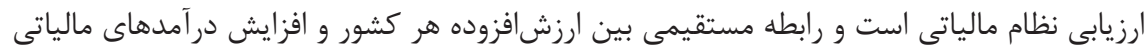
وجود دارد. همجنين، به منظور بررسى جايگًاه استان خوزستان، درآمدهاى مالياتى استانهاى كشور

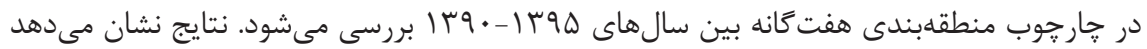
در منطقه اول، استان تهران بالاترين دريافتى درآمدهاى مالياتى را دارد، و استان خوزستان يس از مرسى استانهاى تهران و اصفهان، رتبه سوم دريافت درآمدهاى مالياتى را دارد. ضمن آن كه در سال هاى رداى اخير، سهم درآمدهاى مالياتى مستقيم استان كاهش و سهم در آمدهاى مالياتى غيرمستقيم (ماليات

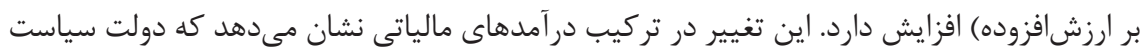
مالياتستانى خود را از طرف توليد به سمت مصرف تغيير داده است.

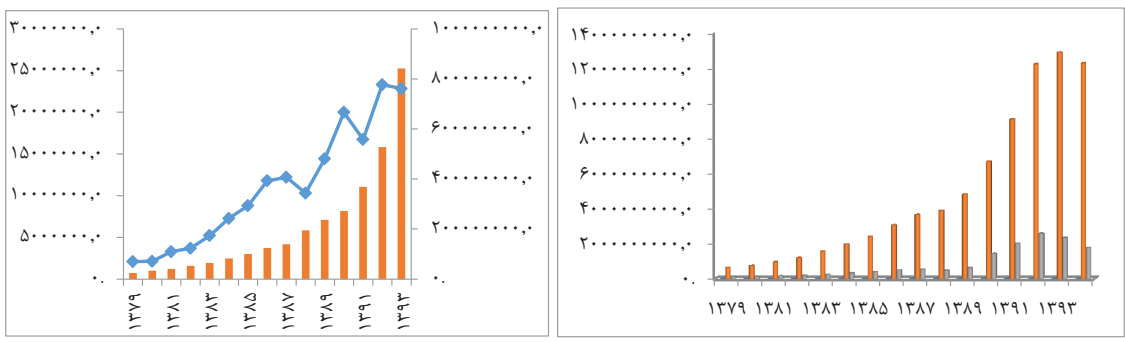

نمودار ا: ارزش افزوده استان در مقايسه با كشور نمودار با: در آمد مالياتى و ارزش افزوده بخش صنعت استان

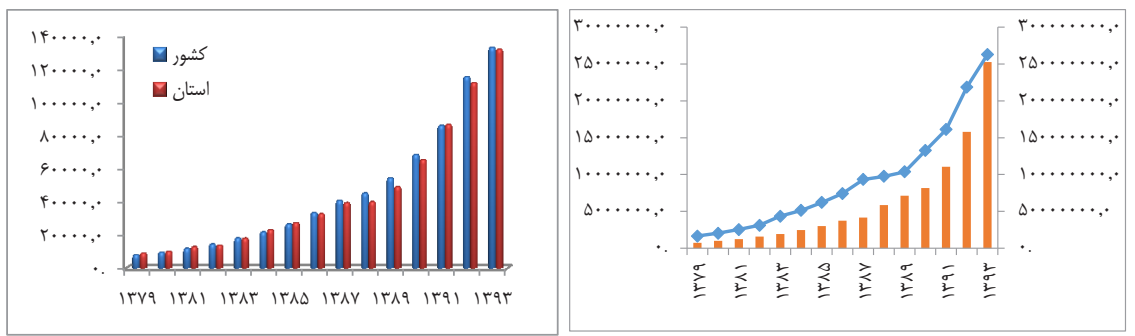

نمودار بّ: در آمد مالياتى و ارزش افزوده بخش خدمات استان نمودار †: توليد ناخالص داخلى سرانه با نفت ـ هزار ريال

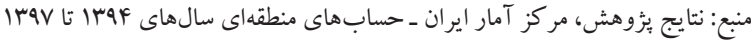


در سالهاى اخير، سياستهاى معطوف به ايجاد اصلاحات در نظام مالياتى و احياى وظايف

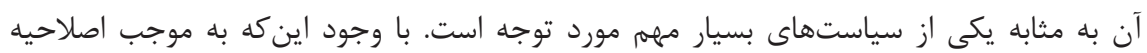

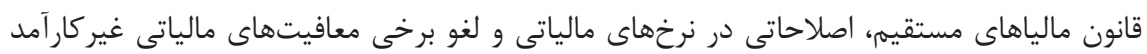
و تبعيضآميز صورت گرفت و از سوى ديكر، اجراى قانون تجميع عوارض و ساماندهى نظام اخذي مانى عوارض و مالياتهاى غيرمستقيم در دستور كار دولت قرار گرفت، اما نتايج لازم بهدست نيامد. بديهى است، دستيابى به نظام كارامد مالياتى و كاهش شكاف بين ظرفيت مالياتى و عملكرد مالياتى، علاوه

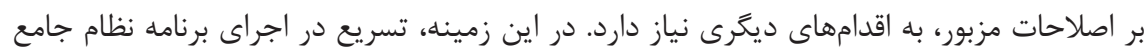

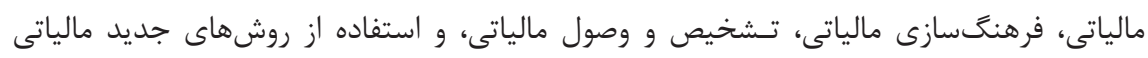

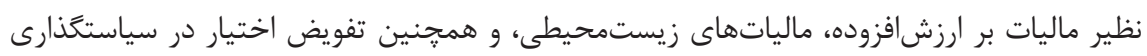

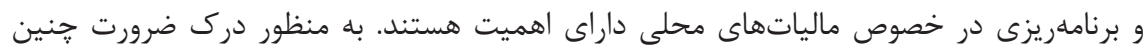

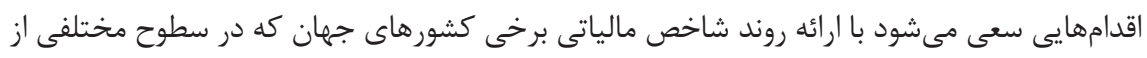

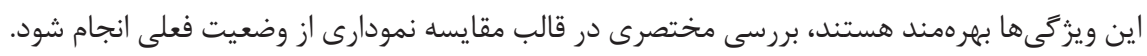

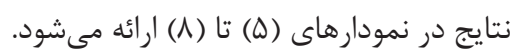
نمودارهاى ذيل نسبت مالياتى كشورهاى جهان در مناطق مختلف، كشور، و استانهاى ايران

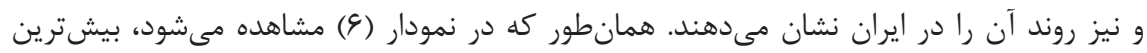

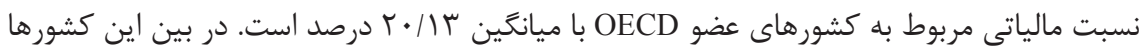

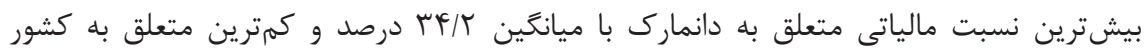

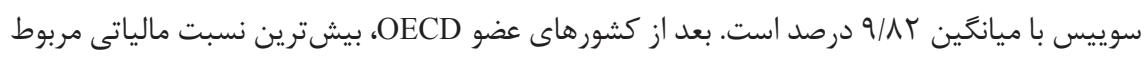

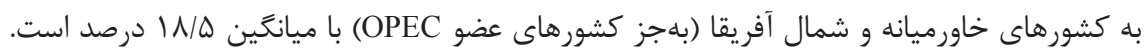

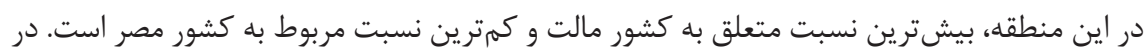

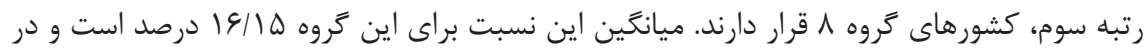

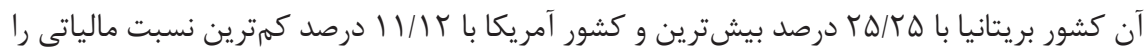

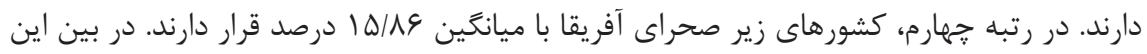

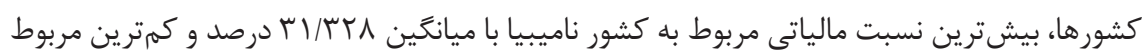

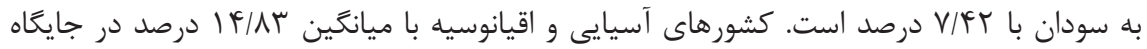

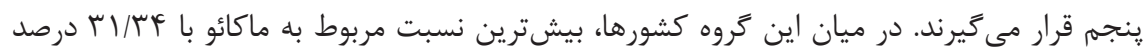

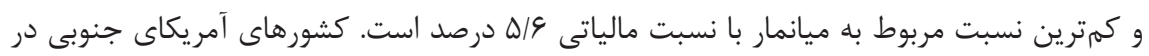


رتبه بعدى قرار دارند. ميانگين نسبت مالياتى در اين كشورها F/OV درصد و كمترين نسبت مربوط

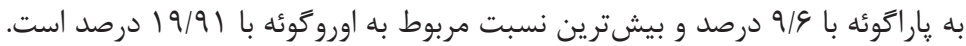

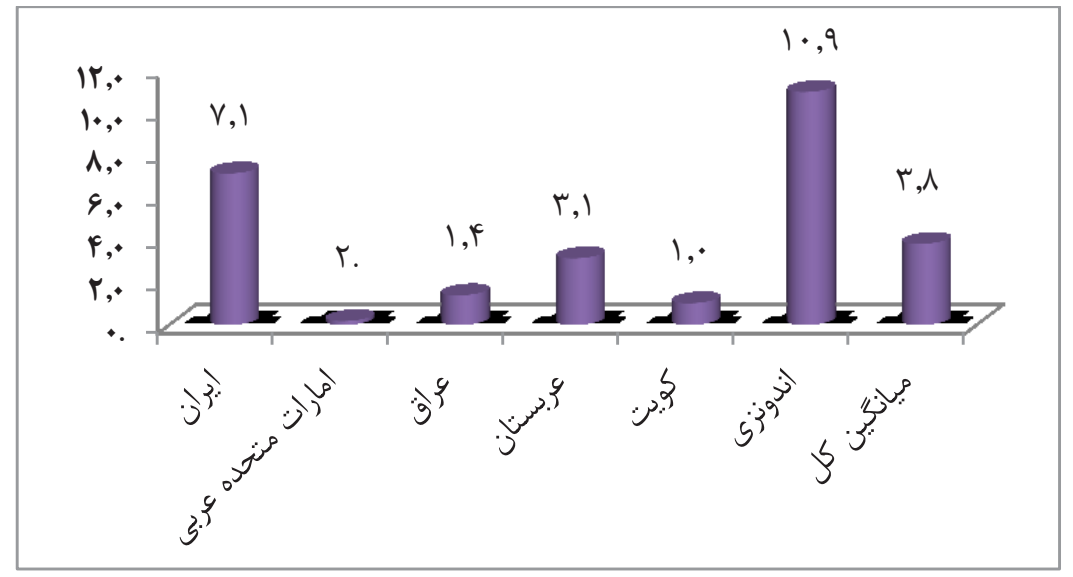

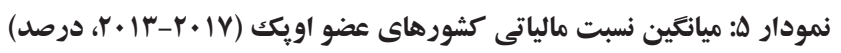

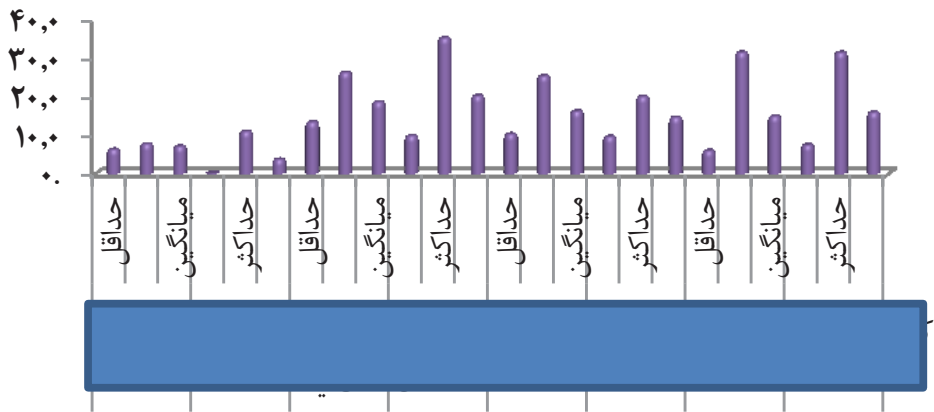

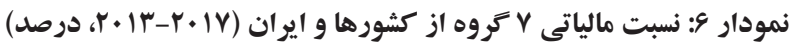




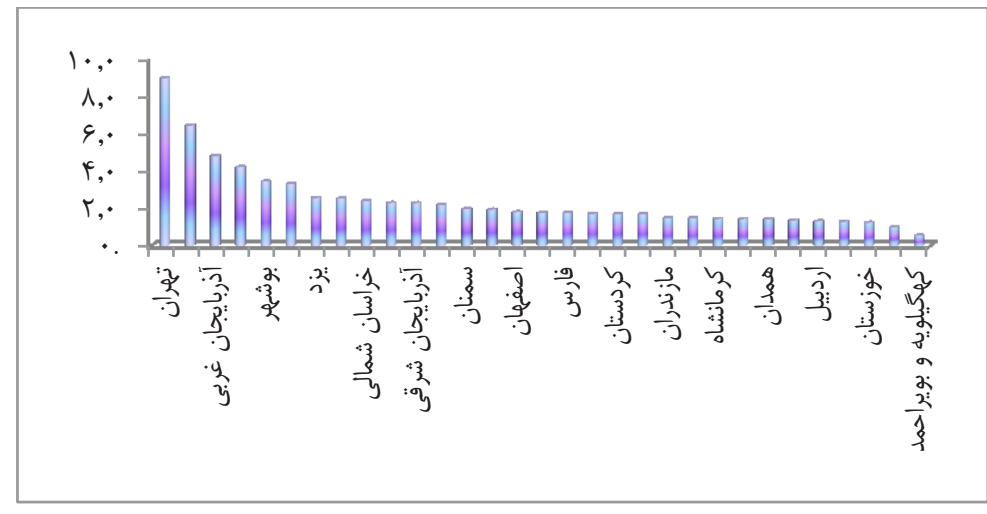

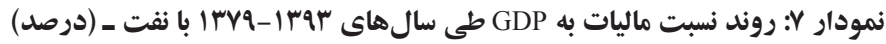

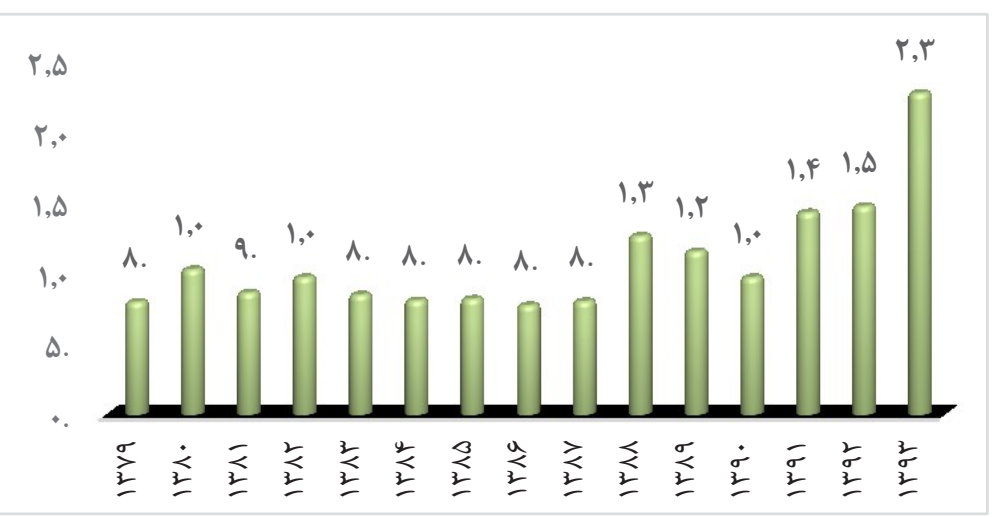

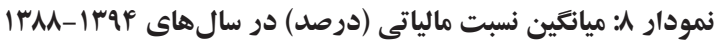

يايينترين ميانكَين نسبت مالياتى به كشورهاى عضو OPEC تعلق دارد. در اين گروه كه ايران

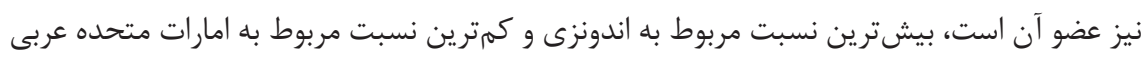

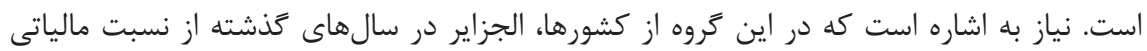

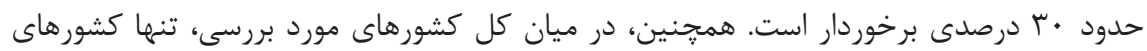

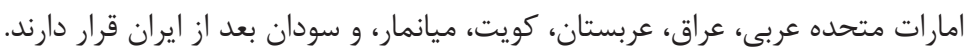




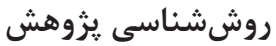

\section{ايستايى متغيرها}

روش سنتى اقتصادسنجى براى برآورد ضرايب مدل بر اين فرض استوار است كه متغيرهاى الكو

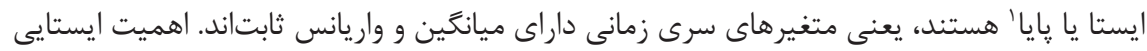
متغير براى يك فراگرد تصادفى در دوره زمانى بلند اين است كه بخواهيم اثر شوك واردشده بر آن

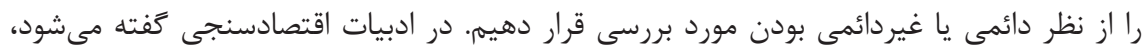

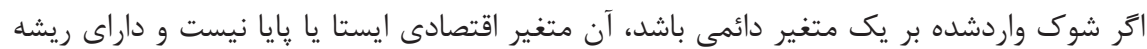

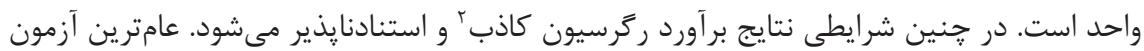

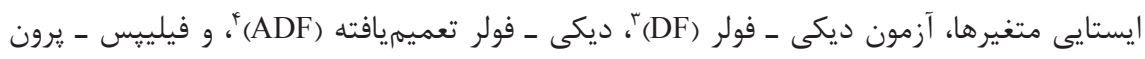

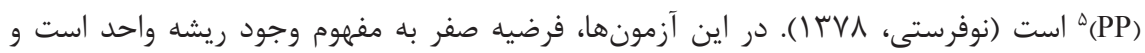
فرضيه مقابل نشاندهنده ايستايى سرى زمانى متغير مورد نظر است. اتر متغيرهاى يكى الكو ايستا

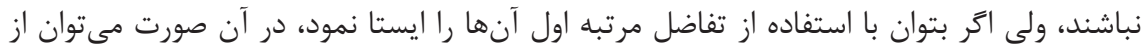
برآورد رَرسيون كاذب جلو كيرى كرد، ولى براى حفظ اطلاعات بلندمدت در رابطه با سطح متغيرها،

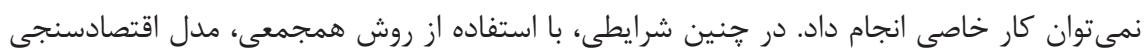
بدون هراس از كاذب بودن برآورد مىشود. نكته مهمم اين است كه بررسى ايستايى متغيرها نيز

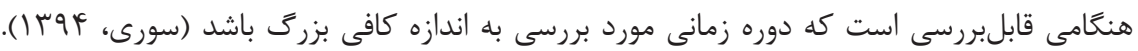

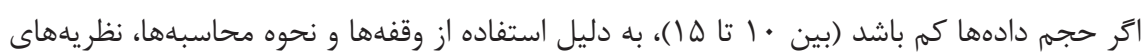
مجانبى برقرار نمىشوند، از اينرو بررسى ايستايى متغيرها قابليت ارزيابى و اتكا ندارد. بنابراين، كفته

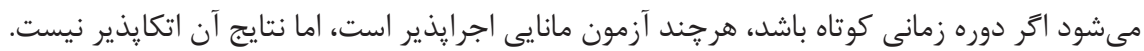

\section{روش ركرسيون بهظاهر نامرتبط (SUR)}

در اين يزوهش، به منظور برآورد ظرفيت مالياتى استان خوزستان از روش رگرسيون بهظاهر

1. Stationary

2. Spurious

3. Dickey-Fuller Test

4. Augmented Dickey-Fuller Test

5. Philips-Perron Test

6. Seemingly Unrelated Regression 


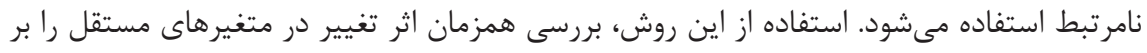

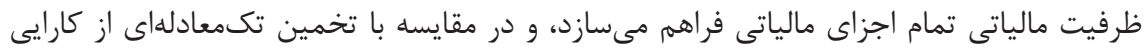

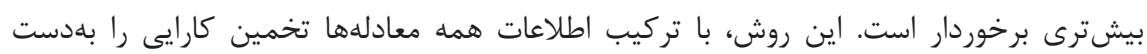

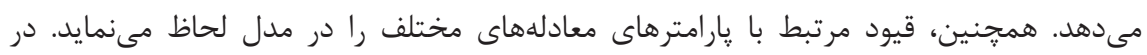

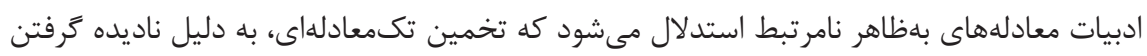

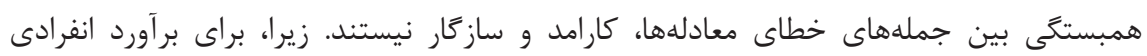

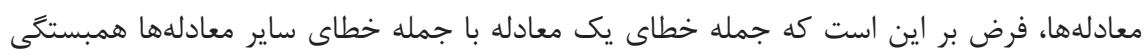

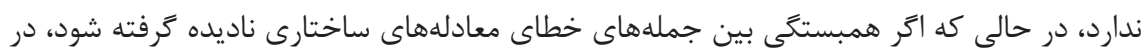

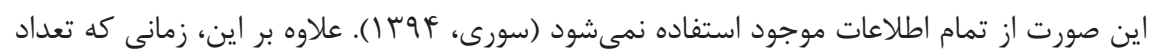

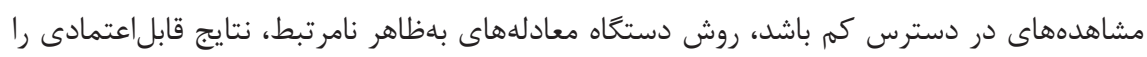

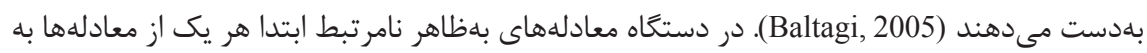

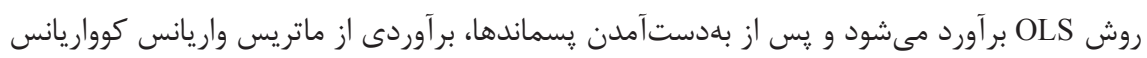

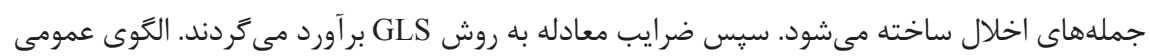
معادلههاى بلهاهر نامر تبط به شرح ذيل است:

$T j=C(1)+C(2) * R+C(3) * R I+C(4) * y$

$T c=C(5)+C(6) * R S+C(7) * R I$

$T f=C(8)+C(9) * R S+C(10) * R I+C(11) * s 1$

$T h w=C(12)+C(13) * g+C(14) * h$

$I D T=C(15)+C(16) * P+C(17) * m$

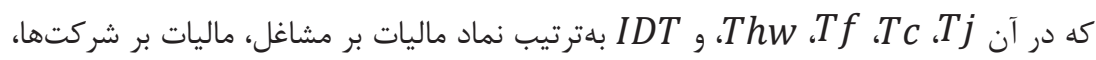

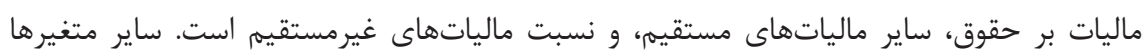

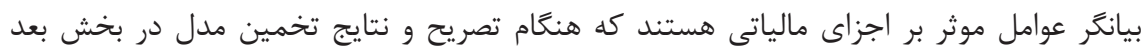
تعريف مىشوند. 


\section{دادهها، تصريح مدل، و تخمين كشش در آمدى و ظرفيت مالياتى استان خوزستان}

با استفاده از دادههاى مالياتى' و اقتصادى استان (سازمان امور مالياتى و مركز آمار ايران)، در دوره

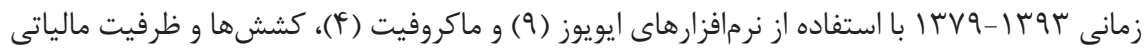
استان تخمين زده مىشود، به علاوه، بر اساس ادبيات يزوهش، مدل كلى ظرفيت مالياتى استان بر اساس ارزشافزوده بخشها، توزيع درآمد، و در آمد سرانه به شرح رابطه (r) ارائه مىشود: $T / G D P_{t}=f\left(\right.$ Manu $\left._{t}, \operatorname{Serv}_{t}, g d p_{t}\right)$

كه در آن: T/GDPt: نسبت مالياتى كل استان (نسبت مالياتهاى مستقيهم به تفكيك اجزاى آن و نسبت مالياتهاى غيرمستقيم به توليد ناخالص داخلى استان خوزستان) (Amoh, 2019)، : سهمم ارزشافزوده بخش صنعت (شامل صنعت، معدن، ساختمان، آب، برق، و كاز) از Servt و خردهروشى، مستغلات و كرايه، خدمات، مالى، اجتماعى و بهداشتى) از GDP استان، و درآمد سرانه استان (Fenochietto \& Pessino, 2013) است كه با توجه به اين كه بخش كشاورزى از مهاز

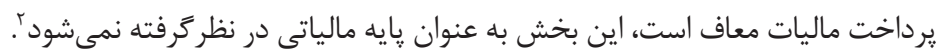

\section{كشش در آمدى ماليات در استان}

كشش درآمدى مالياتى منعكس كننده واكنش سيستم مالياتى به تغييرهاى توليد ناخالص داخلى با

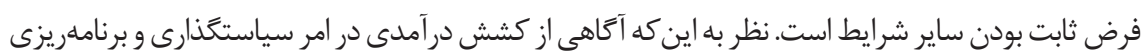
استانى داراى اهميت است و در زمينه شناخت رفتار جامعه اطلاعات مفيدى در اختيار مسئولان استانى

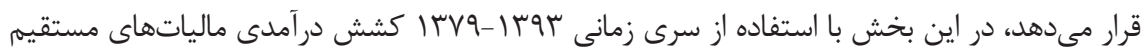

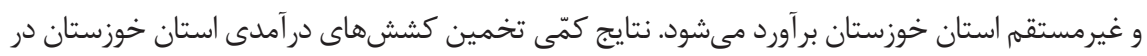

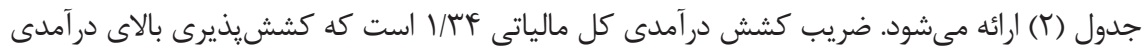

ا. براى استخراج سرى زمانى دادههاى مالياتى استان خوزستان محدويتهاى آمارى زيادى وجود دارد. يس

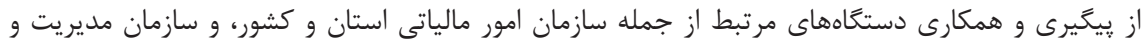

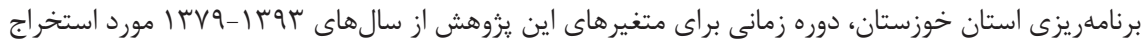

2. http://www.intamedia.ir/Pages/Action/LawsIndex/1 و استفاده قرار مى تيرد. 


\begin{tabular}{|c|c|}
\hline & گروه \\
\hline $\begin{array}{c}L T S=r \cdot|\xi|+r / \mid \cdot L G D P \\
(-\wedge / \Delta \Delta)(\mid / / \vee q)\end{array}$ & TS ماليات بر مصرف و فروش \\
\hline
\end{tabular}

نياز به اشاره است كه كميجانى و فهيم يحيايى (••rVI)، در خصوص تركيب در آمدهاى مالياتى كل كشور به بررسى انواع كششيذيرى در اجزاى مالياتى كشور مىيردازند. بر اساس نتايج اين

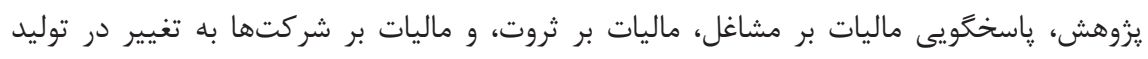

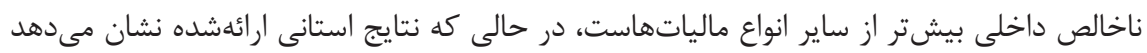
كه بهترتيب كششيذيرى ماليات بر مصرف و فروش، ماليات بر ثروت، و ماليات بر شركت از بقيه بيشتر است و ماليات بر مشاغل كشش كمترى دارد.

\section{تخمين توابع ظرفيت مالياتى استان}

در اين بخش، براى تخمين ظرفيت مالياتى استان به تفكيك زيربخشها، جهار معادله رفتارى شامل نسبت مالياتى به تفكيك ماليات بر مشاغل، ماليات بر شركتها، ساير مالياتهاى مستى مستقيم

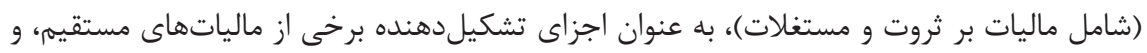

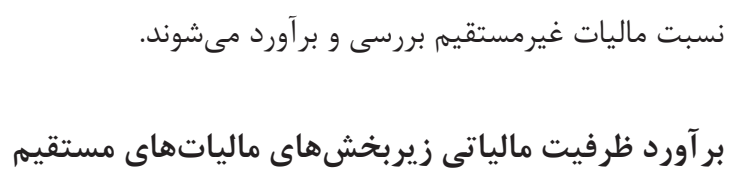

همانطور كه در بخش روششناسى يزوهش اشاره مىشود، به منظور در نظرگرفتن همبستخى

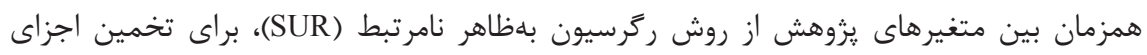

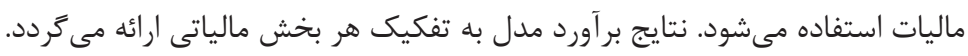

\section{بر آورد ظرفيت مالياتى مشاغل}

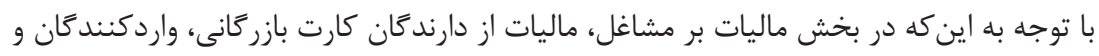

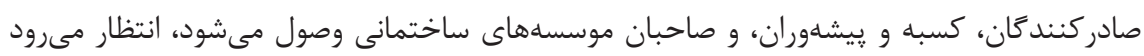


كه اين نوع از مالياتها، تابعى از ارزشافزوده بخش بازر كانى، رستوران، و هتلدارى باشد. بر اساس اين،

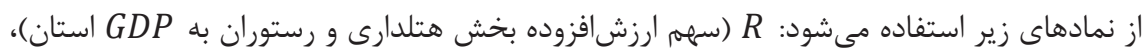

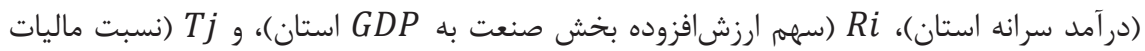

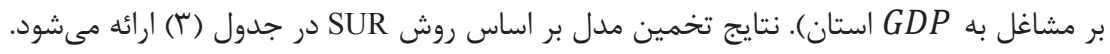

\section{جدول "ّ: نتايج بر آورد ماليات بر مشاغل}

\begin{tabular}{|c|c|c|c|c|}
\hline آماره احتمال & آماره t & انحراف معيار & ضريب & متغير \\
\hline$\cdot 10 \cdot T G$ & . I9VTV & $\cdot / \cdot r \Delta \Lambda$ & $\cdot / \cdot \cdot 1 V$ & RI \\
\hline$\cdot 1 \cdot 9 .$. & r/990. & $.1 . k \& q$ & - IIEFFA & $\mathrm{R}$ \\
\hline$\cdot 1 \cdot \cdots$ & $\cdot 1 \cdot V \wedge F$ & $\cdot \cdot \cdot r F$ & - MTtF & PY \\
\hline - IDTVT & -.|Gror & . & $-\cdot / \cdot \mid l f$ & $\mathrm{C}$ \\
\hline $\mathrm{R}^{2}=\cdot 199$ & $D W=I / \Lambda T$ & & & \\
\hline
\end{tabular}

همانطور كه در جدول (r) ملاحظه مىشود، ضريب ارزشافزوده بخش هتلدارى و رستوران

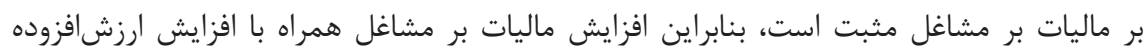

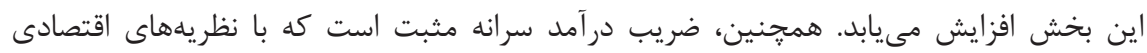
سازكار است. اين ضريب نشان مىدهد با افزايش در آمد سرانه، ميزان اخذ ماليات بر مشاغل افزبايش

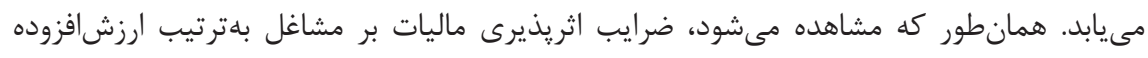

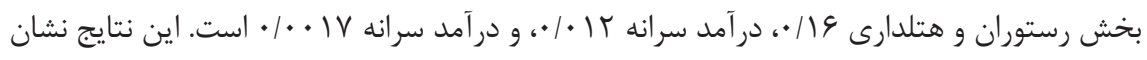
مى دهد كه اثريذيرى ظرفيت مالياتى مشاغل استان بيشتر متاثر از سطح رفاهى استان (در آمد سرانه)

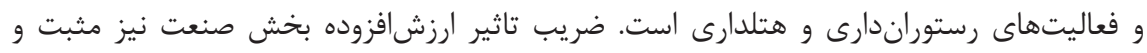
مطابق انتظار است، ولى از نظر آمارى معنادار نيست. يكى از دلايل نبود معنادارى ضريب ارئ ارزشافزوده

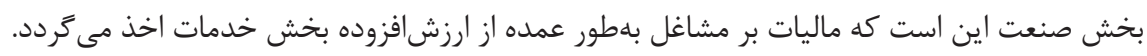

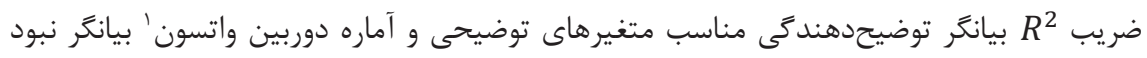
خودهمبستگى سريالى ميان جملههاى اخلال مدل است. 


\section{بر آورد ظرفيت مالياتى شر كتها}

״ايه مالياتى درآمد شركتها شامل درآمدهاى شركتهاى خصوصى، شركتهاى دولتى، و غيردولتى است. بنابراين، براى تخمين ظرفيت مالياتى شركتها از نمادهاى زير استفاده مىشود:

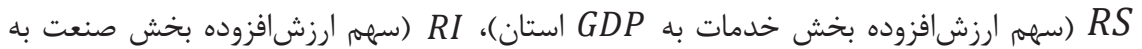
GDP تخمين مدل بر اساس روش SUR در جدول (أ) ارائه مىشود.

\section{جدول †: نتايج بر آورد ماليات بر شركتها}

\begin{tabular}{|c|c|c|c|c|}
\hline آماره احتمال & آماره t & انحراف معيار & ضر يب & متغير \\
\hline $.1 . .99$ & T/gFYq & $\cdot 1 \cdot \cdot r q$ & $\cdot 1 \cdot \cdot \vee 9$ & RI \\
\hline$\cdot / \cdot \Delta \cdot r$ & T/T\&GA & $\cdot 1 \cdot \cdots 4$ & $. / \cdot \mid l$ & $\mathrm{RS}$ \\
\hline$\cdot 10119$ & $-\cdot|\Delta \Delta M|$ & $\cdot \mid \cdot$ TIV & $-\cdot 1 \cdot 1 T \cdot$ & $\mathrm{C}$ \\
\hline $\mathrm{R}^{2}=\cdot 199$ & $\mathrm{DW}=1 / 91$ & & & \\
\hline
\end{tabular}

همانطور كه در جدول (F) ملاحظه مىشود، درآمد سرانه از مدل حذف مىشود. زيرا اين متغير

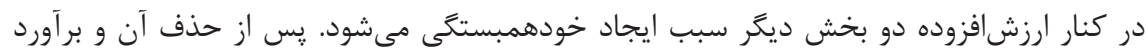
مجدد مدل، ضمن رفع خودهمبستكى ايجادشده، معنادارى كل مدل نيز بهبود مىيابد. يكى از دلايل اين امر وجود همزمان ارزشافزوده دو بخش صنعت و خدمات در كنار يكديخر است. همانطور كه مده ملاحظه مىشود، رابطه بين ارزشافزوده صنعت و خدمات با ماليات بر شركتها مثبت و معنادار

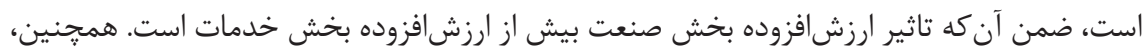
اثريذيرى ظرفيت مالياتى شركتها نسبت به ارزشافزوده بخش خدمات f | \& • • • است، ولى اين بخش از در آمدهاى مالياتى استان با سطح رفاهى (درآمد سرانه) رابطه معنادارى ندارد. نكته مهرم اين

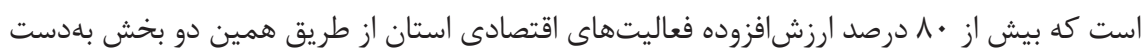

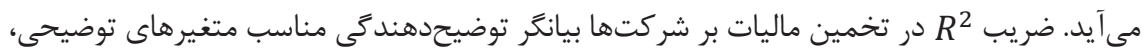
و آماره دوربين واتسون بيانكر نبود خودهمبستكى سريالى ميان جملههاى اخلال مدل است. 
ساير مالياتهاى مستقيم (شامل ماليات بر ثروت و ماليات بر مستغلات)

״ايه مالياتى ماليات بر مستغلات از درآمدى كه با واگذارى املاك به اجاره عايد مى گردد، وصول

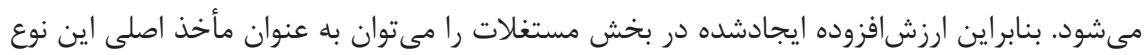
ماليات و در نتيجه عوامل اثر گذار بر آن قلمداد كرد. به علاوه، در بخش يايه مالياتى ثروت بايد توجه

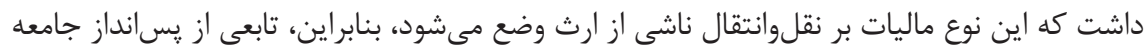

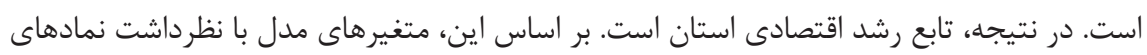

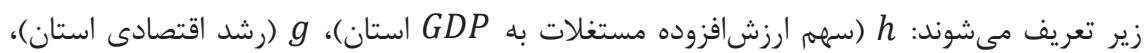
و Thw (نسبت مجموع ماليات بر مستغلات و ماليات بر ثروت به GDP استان) مورد بررسى قرار مى گيرد. نتايج تخمين مدل بر اساس روش SUR در جدول (ل) ارائه مىشود.

جدول ه: نتايج بر آورد ساير مالياتهاى مستقيم (ثروت و مستغلات)

\begin{tabular}{|c|c|c|c|c|}
\hline آماره احتمال & آماره t & انحراف معيار & ضريب & متغير \\
\hline$\cdot / \cdot \wedge$. & $r / l \cdot V q$ & 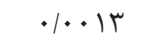 & $\cdot / \cdot r \Lambda$ & g \\
\hline$\cdot 1 \ldots$ & $r / \cdot r \Delta \Lambda$ & 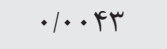 & $.1 \cdot 1 r q$ & $\mathrm{~h}$ \\
\hline$\cdot 14 \cdot 19$ & $-/ r \Delta \cdot r$ & .1 .490 &.$- / .1 V \mu$ & $\mathrm{C}$ \\
\hline
\end{tabular}

$$
\mathrm{R}^{2}=\cdot / \Lambda \mathrm{r} \quad \mathrm{DW}=\mathrm{r} / \cdot 1
$$

همانطور كه ملاحظه مىشود، رابطه بين رشد اقتصادى و ارزشافزوده بخش مستغلات استان با ساير مالياتها (ماليات بر مستغلات و ثروت) از نظر آمارى مثبت و معنادار است. بنابراين، انتظار

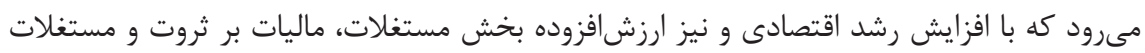
افزايش يابد. ملاحظه مىشود كه اثريذيرى ظرفيت مالياتى ساير مالياتهاى مستقيم استان (ثروت

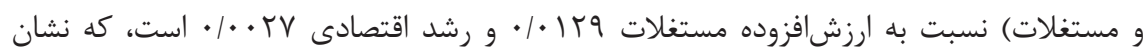
مى دهد ارزشافزوده مستغلات نسبت به رشد اقتصادى تاثيرگذارى بيشترى بر ظرفيت مالياتى اين

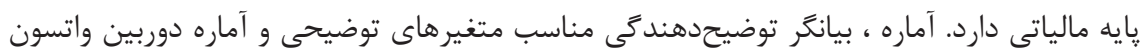
بيانكر نبود خودهمبستگى سريالى ميان جملههاى اخلال است. 


\section{بر آورد ظرفيت مالياتى مالياتهاى غيرمستقيم}

در بخش مالياتهاى غيرمستقيم، بلويزه ماليات بر مصرف و فروش، رفتار مصرفكننده در ميزان

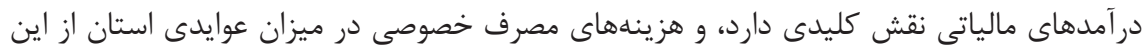
نوع از ماليات داراى اهميت است. در اين مدل متغيرها، با نظرداشت نمادهاى زير تعريف مىشوند: (سهم ارزشافزوده بخش معدن - به عنوان بخشى از ارزشافزوده بخش صنعت كه مشمول يرداخت

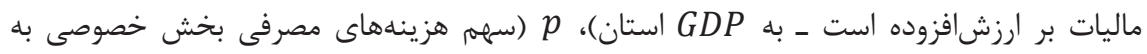
GDP غيرمستقيم مورد بررسى قرار مى گيرد. نتايج تخمين مدل بر اساس روش SUR در جدول (9) ارائه

\begin{tabular}{|c|c|c|c|c|}
\hline \multicolumn{5}{|c|}{ جدول \&: نتايج بر آورد مالياتهاى غيرمستقيم } \\
\hline آماره احتمال & t & انحراف معيار & 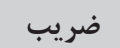 & 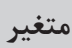 \\
\hline$\cdot \cdots$ & $r / \Lambda F \Delta \Delta$ & $\cdot|\cdot \Delta|$ & .1 .194 & $\mathrm{P}$ \\
\hline$\cdot 1 \cdots$ & g/KTाA & $\cdot 1 \cdot \cdots 1$ & $\cdot / \cdots \Delta$ & M \\
\hline$\cdot / V \cdot 9 V$ & -.119rvar & $\cdot 11 \cdot 19$ & $-.1 \cdot 19 \mathrm{~V}$ & $\mathrm{C}$ \\
\hline $\mathrm{R}^{2}=\cdot 1 \mathrm{M} \Lambda$ & $\mathrm{DW}=1 / \wedge 9$ & & & \\
\hline
\end{tabular}
مخارج مصرفى و ارزشافزوده بخش معدن مشمول ماليات بر ارزشافزوده، مالياتهاى غيرمستقيم

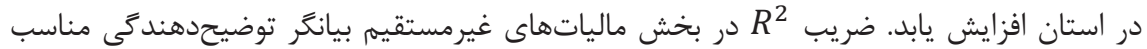

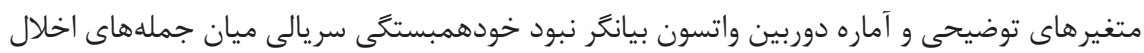

\section{بحث و نتيجه گيرى}

هدف اين يروهش تخمين كششهاى درآمدى و برآورد ظرفيت مالياتى استان خوزستان است.

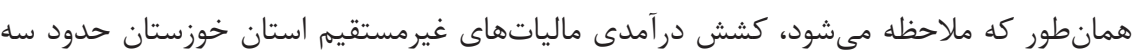


برابر مالياتهاى مستقيم استان است، و كشش درآمدى كل مالياتهاى استان نيز اكر خه كمتر است،

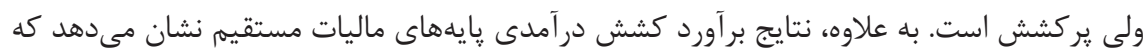

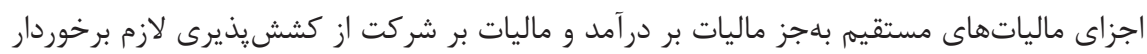

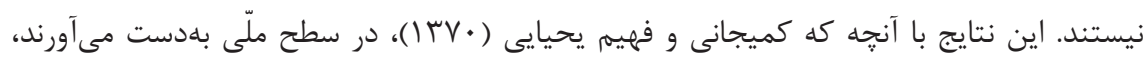

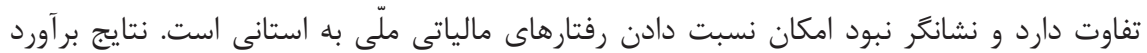

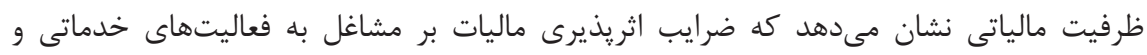

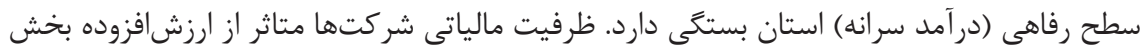

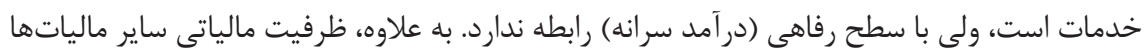

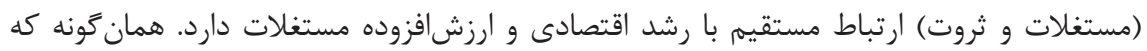

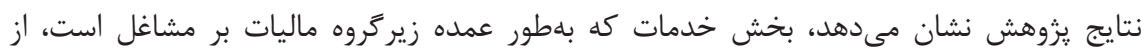

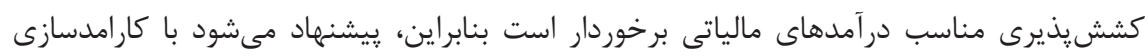

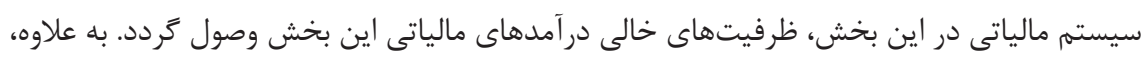

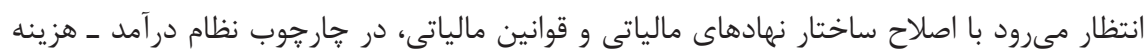

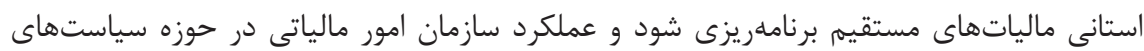

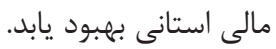

نظر به اين كه كشش مالياتهاى غيرمستقيم بسيار بيشتر از مالياتهاى مستقيم است، بيشنهاد مىشود از اين متغير سياستى در جهت تثبيت و تصحيح فعاليتهاى اقتصادى استانى استفاده

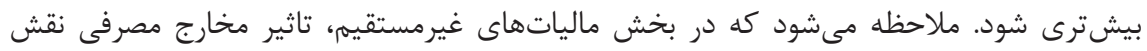

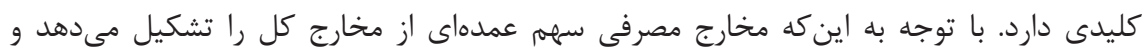

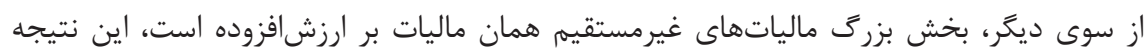

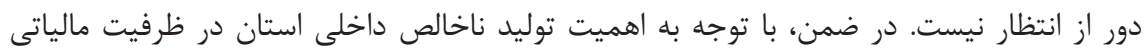

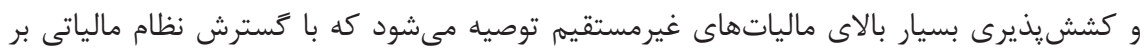

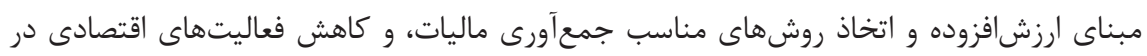

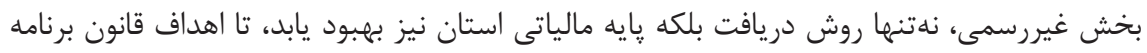

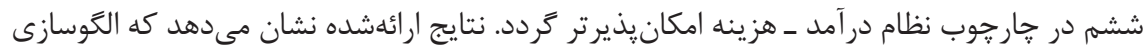

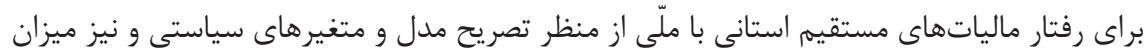

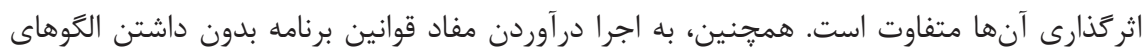


استانى دور از انتظار به نظر مىرسد. با اهميت اجرايى شدن نظام درآمد-هزينه استانى و كاهش

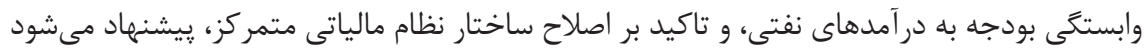

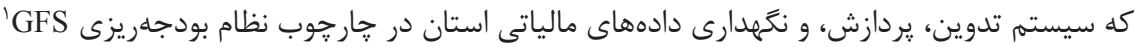
انجام شود تا با محدوديت آمارى براى بررسى و تخمين مدل مواجه نشويم.

يروين، سهيلا، و قرهباغيان، مصطفى (س (IrVY). برآورد ظرفيت مالياتى در /ستانهاى مختلف كشور. طرح تحقيقاتى معاونت امور اقتصادى وزارت امور اقتصاد و دارايى.

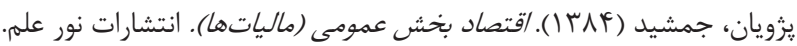

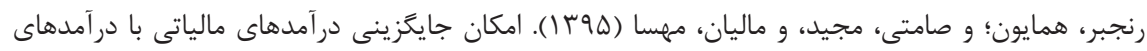

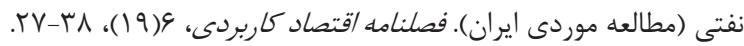

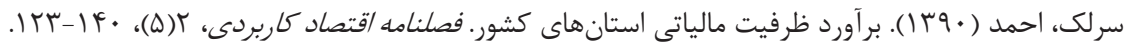

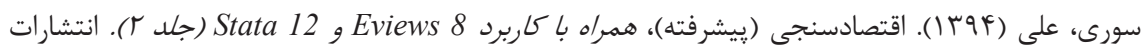
فرهنخشناسى.

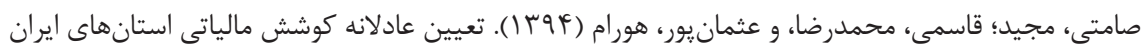

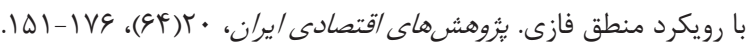

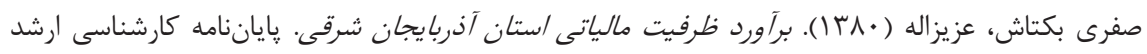
دانشكاه تهران. عربمازار، عباس، و زاير، آيت (1) (IVV). برآورد ظرفيت بالقوه اقتصادى ماليات در ايران. مجموعه مقالات دومين

$$
\text { همايش سياستهاى مالى و مالياتى /يران. }
$$

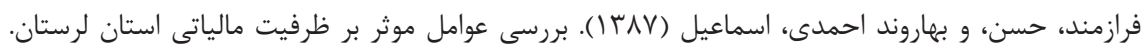

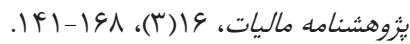

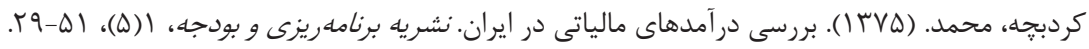

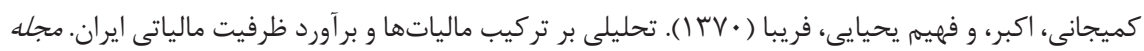

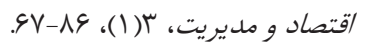




$$
\begin{aligned}
& \text { كرايىنزاد، غلامرضا، و جيردار، الهه (1) (1). بررسى عوامل موثر بر درآمدهاى مالياتى در ايران. فصلنامه علوم }
\end{aligned}
$$

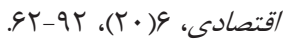

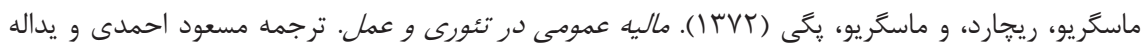

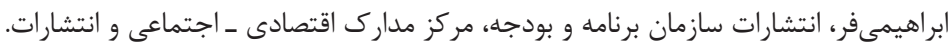

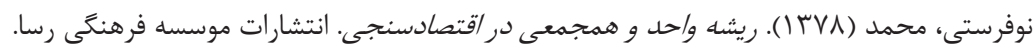

Amoh, J. K. (2019). An Estimation of the Taxable Capacity, Tax Effort and Tax Burden of an Emerging Economy: Evidence from Ghana. International Journal of Economics and Financial Issues, 9(3), 12-21.

Baltagi, B. H. (2005). Econometric Analysis of Panel Data, John Wiley \& Sons Ltd.

Basand, J., Chelliah, J., Margaret, R., \& Kelly, R. (1976). Tax Ratios and Tax Effort in Developing Countries, 1969-71. IMF Staff papers, 22(1), 42-91.

Castells, A., Esteller, A., \& Vilalta, M. (2003). Tax Capacity Disparities and Fiscal Equalization: The Case of Spanish Local Governments. Documents de Treball.

Chelliah, R. J. (1971). Trends in Taxation in Developing Countries. Staff Papers, 18(2), 254-331.

Fenochietto, R. \& Pessino, C. (2013). Understanding Countries'Tax Effort. IMF Working Paper No. 13244/.

Goode, R. (2010). Government Finance in Developing Countries: Brookings Institution Press.

Karagöz, K. (2013). Determinants of Tax Revenue: Does Sectorial Composition Matter? Journal of Finance, Accounting \& Management, 4(2), 50-63.

Le, T. M., Moreno-Dodson, B., \& Rojchaichaninthorn, J. (2008). Expanding Taxable Capacity and Reaching Revenue Potential: Cross-Country Analysis: The World Bank.

Luky, A. (2003). Estimate of Estochastic Frontier Tax Potential: Can Indonesian Local Governments Increase Tax Revenues Under Decentralization? Working Paper, No. 2.

Mankiw, N. G. (2000). The Savers-Spenders Theory of Fiscal Policy. American Economic Review, 90(2), 120-125.

Musgrave, R. (1987). Tax Reform in Developing Countries. The Theory of Taxation in Developing Countries. Newbery, D. and Stern, N: New York: Oxford University Press.

Sobarzo, H. (2004). Tax Effort and Tax Potential of State Governments in Mexico: A Representative Tax System. Working Paper. No. 315.

Tait, A. A., Grätz, W. L., \& Eichengreen, B. J. (1979). International Comparisons of Taxation for Selected Developing Countries, 197276-. Staff Papers, 26(1), 123-156. 